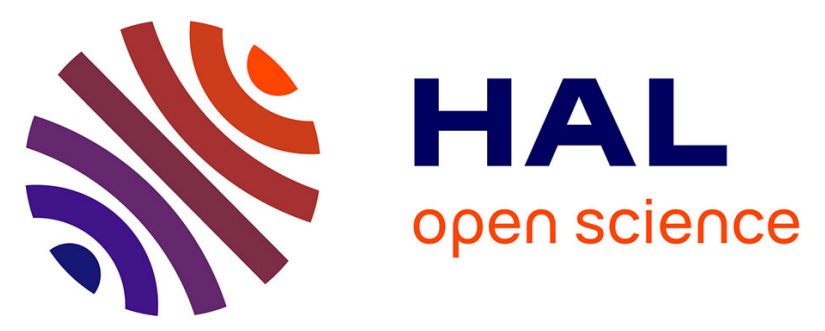

\title{
Rhodium(I) Complexes of New Ferrocenyl \\ Benzimidazol-2-ylidene Ligands: The Importance of the Chelating Effect for Ketone Hydrosilylation Catalysis
}

Süleyman Gülcemal, Agnès Labande, Jean-Claude Daran, Bekir Çetinkaya, Rinaldo Poli

\section{To cite this version:}

Süleyman Gülcemal, Agnès Labande, Jean-Claude Daran, Bekir Çetinkaya, Rinaldo Poli. Rhodium(I) Complexes of New Ferrocenyl Benzimidazol-2-ylidene Ligands: The Importance of the Chelating Effect for Ketone Hydrosilylation Catalysis. European Journal of Inorganic Chemistry, 2009, N-Heterocyclic carbene complexes, 2009 (13), pp.1806-1815. 10.1002/ejic.200801163 . hal-03184576

\author{
HAL Id: hal-03184576 \\ https://hal.science/hal-03184576
}

Submitted on 29 Mar 2021

HAL is a multi-disciplinary open access archive for the deposit and dissemination of scientific research documents, whether they are published or not. The documents may come from teaching and research institutions in France or abroad, or from public or private research centers.
L'archive ouverte pluridisciplinaire HAL, est destinée au dépôt et à la diffusion de documents scientifiques de niveau recherche, publiés ou non, émanant des établissements d'enseignement et de recherche français ou étrangers, des laboratoires publics ou privés. 


\title{
Rhodium(I) complexes of new ferrocenyl benzimidazol-2-ylidene ligands: The importance of the chelating effect for ketone hydrosilylation catalysis.
}

\author{
Süleyman Gülcemal, ${ }^{[a]}$ Agnès Labande, ${ }^{* b][c]}$ Jean-Claude Daran, ${ }^{[b][c]}$ Bekir Çetinkaya ${ }^{[a]}$ and \\ Rinaldo Poli ${ }^{[b][c][d]}$
}

Keywords: N-heterocyclic carbenes / benzimidazole / ferrocene / Rhodium / hydrosilylation

$N$-[(1-Phosphanylferrocen-1'-yl)methyl]- $N^{\prime}-[(2,4,6-$ trimethylphenyl)methyl]-5,6-di-X-benzimidazolium tetrafluoroborate salts $(\mathrm{X}=\mathrm{H}, \mathbf{5} \mathbf{a}$ and $\mathrm{Me}, \mathbf{5} \mathbf{b})$, precursors of new phosphanebenzimidazol-2-ylidene bifunctional ligands, and related ferrocenyl 5,6-di-X-benzimidazol-2-ylidene iodide salts $(X=H, 6 a$ and $\mathrm{Me}$ 6b), precursors of monodentate benzimidazol-2-ylidene ligands, have been prepared for the first time. Cationic rhodium(I) complexes 7a and $\mathbf{7 b}$ and neutral rhodium(I) complexes $\mathbf{8 a}$ and $\mathbf{8 b}$ have been obtained in good yields and fully characterised. Cationic rhodium $(\mathrm{I})$ complexes $\mathbf{1 0 a}$ and $\mathbf{1 0 b}$ were prepared from $\mathbf{8 a}$ and $\mathbf{8 b}$, for comparison with complexes $\mathbf{7}$, but not isolated. [a] Ege University, Department of Chemistry, Bornova, 35100 Izmir, Turkey.

[b] CNRS; LCC (Laboratoire de Chimie de Coordination); 205, route de Narbonne, F-31077 Toulouse, France. Fax: +33561553003.

E-mail : agnes.labande@ @ lcc-toulouse.fr

[c] Université de Toulouse; UPS, INPT; F-31077 Toulouse, France.

[d] Institut Universitaire de France; 103, bd Saint-Michel; F-75005 Paris, France.

\section{Introduction}

The recent developments in the field of functionalised $\mathrm{N}$ heterocyclic carbene (NHC) ligands have proved their great potential in transition metal catalysis. ${ }^{[1-3]}$ Indeed, the presence of an NHC and a second, structurally different donating group on the metal can radically alter the catalytic properties. On the other hand, the chelating nature of these ligands results in the production of highly stable complexes. In our search for more efficient catalysts, we have shown that very small structural variations on bifunctional ligands could change dramatically the reactivity of rhodium(I) catalysts for the hydrosilylation of ketones. ${ }^{[4,5]}$

Although NHC ligands bearing a benzimidazole backbone offer a vast potential for catalytic applications, their coordination chemistry has remained relatively unexplored. ${ }^{[6-12]}$ The $\sigma$-donating properties of benzimidazol-2-ylidene ligands stand between those of unsaturated imidazol-2-ylidenes and of saturated imidazolin-2ylidenes. Thus, although they have the topology of unsaturated NHCs, they show a reactivity typical of saturated carbenes. ${ }^{[11,13]}$

We have tried to improve the catalytic activity of rhodium(I) complexes bearing ferrocenylphosphanyl-NHC ligands. Indeed, ferrocenyl-substituted NHCs are a class of ligands that has been little developed and has a great potential in both asymmetric and non-asymmetric catalysis. ${ }^{[2,14]}$ We thus prepared new ferrocenylphosphane ligand precursors bearing a benzimidazolium
All complexes showed good activities for the catalytic hydrosilylation of acetophenone derivatives. Activities are much greater than for related imidazol-2-ylidene systems and the cationic complexes are more active than the neutral ones, the highest activities being recorded for the more soluble $\mathbf{7 b}$ system. The use of bidentate ligands proved essential to obtain good selectivities in the desired alcohol.

moiety, and the corresponding rhodium(I) complexes. Although benzimidazolium salts with a ferrocenyl substituent are already known, ${ }^{[15]}$ we report here the first example of a ferrocenylphosphane bearing a benzimidazolium unit. In order to evaluate the contribution of the phosphanyl group to catalysis, rhodium(I) complexes bearing monodentate ferrocenyl NHC ligands were also prepared.

\section{Results and Discussion}

(a) Synthesis and characterisation of ligand precursors 5 and

The benzimidazolium salts $\mathbf{4 a}$ and $\mathbf{4 b}$ were obtained in very good yields from ferrocenyl alcohol $\mathbf{1}$ and, respectively, substituted

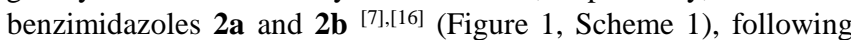
the procedure developed previously in our group for related imidazolium salts. ${ }^{[4]}$

The phosphane group was deprotected by desulfurisation with Raney nickel to afford the ligand precursors $\mathbf{5 a}$ and $\mathbf{5 b}$. Two related systems, either with (b) or without (a) methyl groups at positions 5 and 6 of the benzimidazole moiety were developed, in order to check whether subtle variations could induce electronic changes on the metal centre or modify the physical properties of the metal complexes. ${ }^{[12]}$

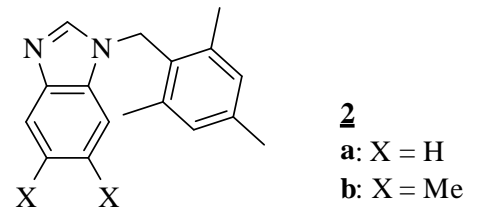

Figure 1. Substituted benzimidazoles. 
In parallel, compounds $6 \mathbf{a}$ and $\mathbf{6 b}$ were prepared by reaction of $\mathrm{N}$-(ferrocenylmethyl) trimethylammonium iodide (3) with substituted benzimidazoles in refluxing acetonitrile (Scheme 2), following the literature procedure. ${ }^{[17]}$ These systems will allow a performance comparison of the benzimidazol-2-ylidene/phopshine ligand systems either in the presence of absence of a chelating effect.
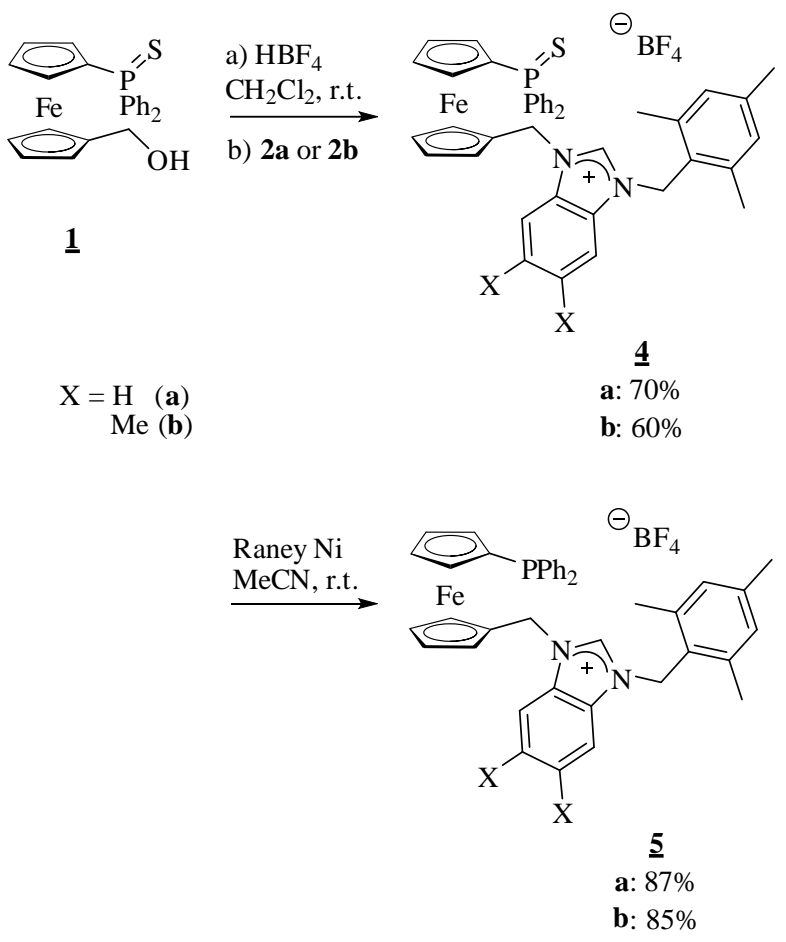

Scheme 1 . Synthesis of 1,1 '-disbustituted ferrocenyl benzimidazolium salts.

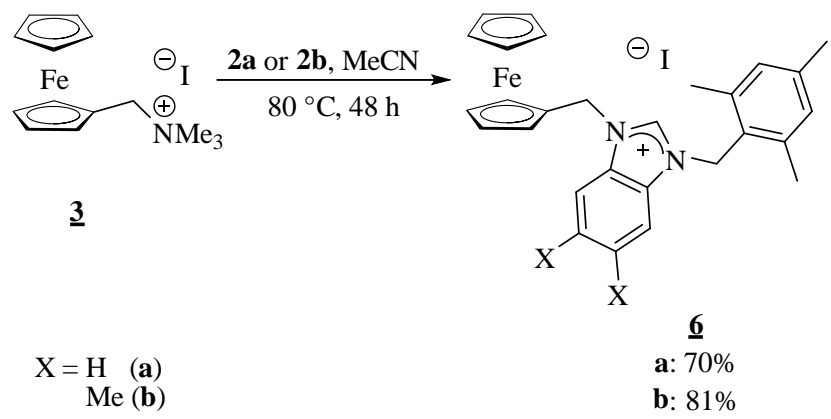

Scheme 2. Synthesis of ferrocenyl benzimidazolium salts.

All compounds were fully characterised by standard analytical methods. The ${ }^{1} \mathrm{H}$ NMR spectra of compounds $\mathbf{5 a}$ and $\mathbf{5 b}$ showed signals at respectively 9.10 and $8.86 \mathrm{ppm}$, characteristic of the acidic $\mathrm{C} 2$ proton of the benzimidazolium group. Comparatively, the signal of the same proton in compounds $\mathbf{6 a}$ and $\mathbf{6 b}$ is shifted downfield (10.60 and $10.21 \mathrm{ppm}$ respectively), due to the stronger $\mathrm{C}-\mathrm{H}^{\cdots} \cdot \mathrm{X}^{-}$bond polarisation when $\mathrm{X}=\mathrm{I}^{[3]}$ The crystal structures of compounds 5a and $\mathbf{6 b}$ have been resolved by X-ray diffraction analysis (Figure 2). The C-C bond of the imidazolium motif is significantly longer in the case of benzimidazolium salts $\mathbf{5 a}$ and $\mathbf{6 b}$ (1.395(3) $\AA$ and 1.399(6) $\AA$, respectively), compared to a 1,1'ferrocenylphosphane imidazolium salt previously described by us $\left[\begin{array}{ll}1.330(6) & \AA\end{array}\right]$. This denotes the delocalization of the C-C bond $\pi$ electron density into the condensed benzene ring (the $\mathrm{C}-\mathrm{C}$ bond lengths within the ring are in the 1.372-1.402 $\AA$ range for $\mathbf{5 a}$ and in the 1.354-1.424 $\AA$ range for $\mathbf{6 b}$ ) and could be responsible for the different reactivity of the resulting carbenes. The two structures show hydrogen bonds, as is typically observed for imidazolium salts, between a fluorine atom of the $\mathrm{BF}_{4}{ }^{-}$anion and the $\mathrm{C} 62$ proton (F3 $\cdots \mathrm{H} 62-\mathrm{C} 62=2.312 \AA$ ) for $\mathbf{5 a}$, and between the iodide anion and the $\mathrm{C} 1$ proton $(\mathrm{I} 1 \cdots \mathrm{H} 1-\mathrm{C} 1=2.962 \AA$ ) for $\mathbf{6} \mathbf{b}$. The H-bond is significantly shorter in the case of benzimidazolium salt 5a, possessing a weakly-coordinating anion, certainly because the $\mathrm{F}$ atom is much smaller than the I atom, although the NMR study (vide supra) indicates a stronger $\mathrm{H}$ bond for the iodide salt.
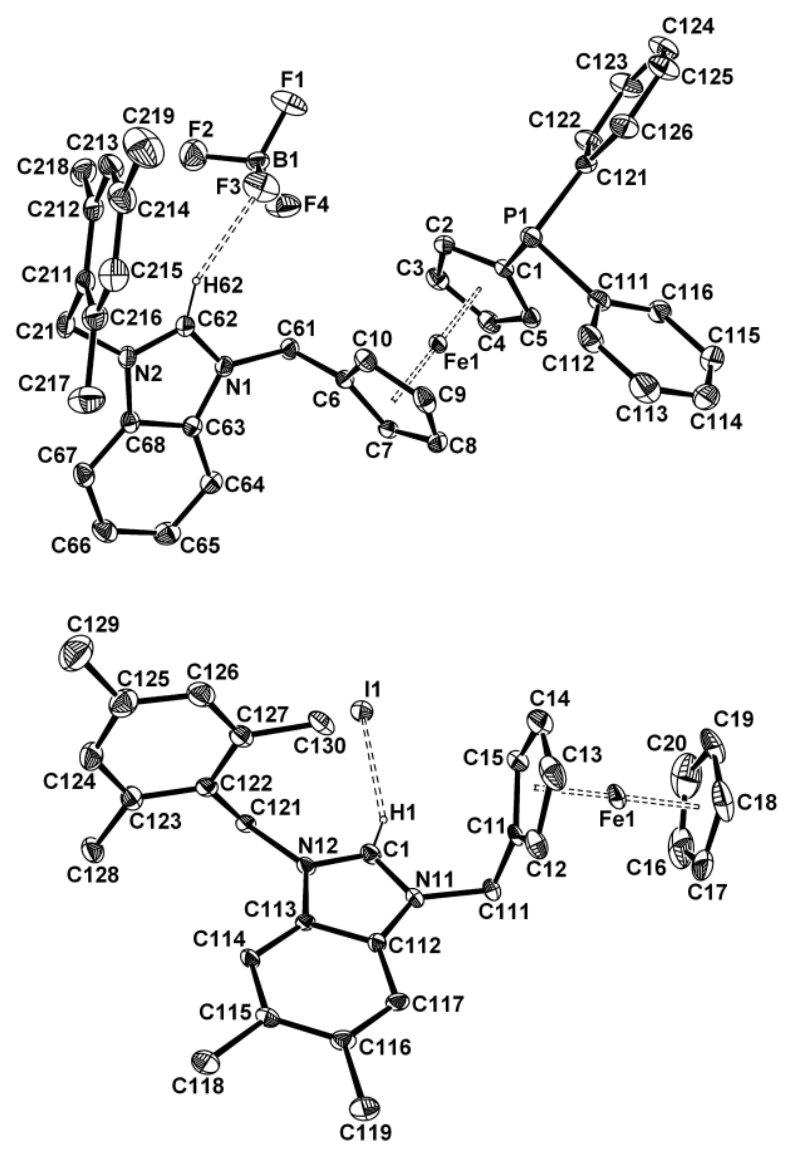

Figure 2. ORTEP views of 5a (top) and $\mathbf{6 b}$ (bottom). Ellipsoids are shown at the $30 \%$ probability level. All hydrogen atoms except $\mathrm{H}(62)$ (top) and $\mathrm{H}(1)$ (bottom) are omitted for clarity. Selected bond lengths ( $\AA$ ) and angles ${ }^{\circ}$ ), 5a: C(1)-P(1) 1.811 (2), C(62)-N(1) 1.325 (3), C(62)-N(2) 1.331 (3), C(63)-C(68) 1.395 (3), N(1)-C(62)-N(2) 110.5 (2) ; 6b: C(1)-N(11) 1.321 (6), C(1)-N(12) 1.321 (6), C(112)-C(113) 1.399 (6), N(11)(C(1)-N(12) $110.4(6)$.

\section{(b) Synthesis and characterisation of rhodium(I) complexes 7} and 8

Addition of compounds $\mathbf{5 a}$ or $\mathbf{5 b}$ to $[\mathrm{Rh}(\mathrm{COD})(\mathrm{O} t \mathrm{Bu})]_{2}-$ prepared in situ from $[\mathrm{Rh}(\mathrm{COD}) \mathrm{Cl}]_{2}$ and $\underline{t} \mathrm{BuOK}^{[18]}-$ in THF led to rhodium(I) complexes $\mathbf{7 a}$ and $\mathbf{7 b}$. $[\mathrm{Rh}(\mathrm{OMe})(\mathrm{COD})]_{2}$ reacted with benzimidazolium salts $\mathbf{6 a}$ and $\mathbf{6 b}$ in dichloromethane to give complexes $\mathbf{8 a}$ and $\mathbf{8 b}$, respectively (Scheme 3 ). The reaction with ligand precursors $\mathbf{5 a}$ and $\mathbf{5 b}$ led directly to cationic complexes, whereas the neutral form was obtained in the case of precursors $\mathbf{6 a}$ and $\mathbf{6 b}$, with iodide coordination.

The ${ }^{13} \mathrm{C}$ NMR signals of the carbene $\mathrm{C}$ atoms of complexes 7 appear at $192.5 \mathrm{ppm}(\mathbf{7 a})$ and $189.9 \mathrm{ppm}(\mathbf{7 b})$, within the expected range for cationic NHC-Rh(I) complexes with a benzimidazol-2- 
ylidene moiety. ${ }^{[10,19]}$ These signals are found at slightly lower fields for complexes $\mathbf{8 a}$ (196.4 ppm) and $\mathbf{8 b}(194.5 \mathrm{ppm}){ }^{[8,18]}$
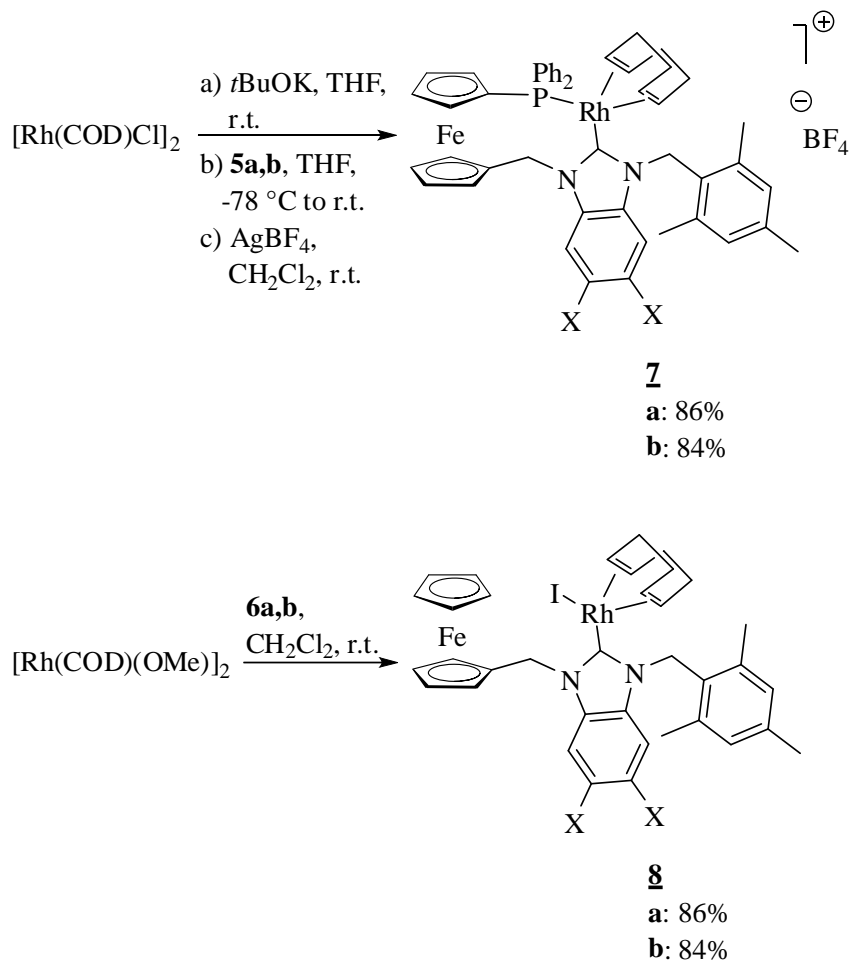

Scheme 3. Synthesis of rhodium complexes.
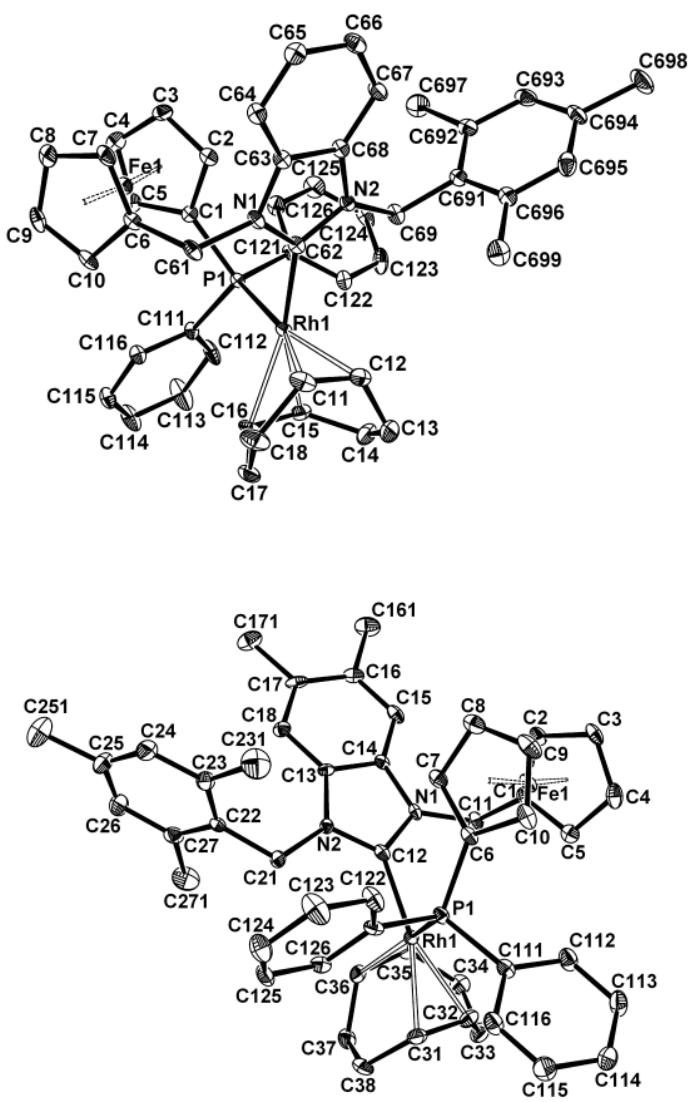

Figure 3. ORTEP views of 7a (top) and $\mathbf{7 b}$ (bottom). Ellipsoids are shown at the $50 \%$ (7a) or $30 \%$ (7b) probability level. All hydrogen atoms are omitted for clarity.
Complexes $\mathbf{7}$ and $\mathbf{8}$ gave X-ray quality crystals by slow diffusion of ether into a dichloromethane solution (Figures 3 and 4). Selected bond distances and angles are listed in Table 1, and compared to those of previously described complex 9a (Figure 5). ${ }^{[4]}$ The squareplanar coordination environment in complexes 7-8 was confirmed by X-ray diffraction studies (Figures 3 and 4). The cis-NHC-Rh-P angles in complexes 7a, 7b $\left(92.06(18)^{\circ}\right.$ and $93.78(12)^{\circ}$, respectively) and the cis-NHC-Rh-I angles in complexes $\mathbf{8 a}, \mathbf{8 b}$ $\left(89.57(6)^{\circ}\right.$ and $86.1(3)^{\circ}$, respectively) are close to the expected $90^{\circ}$ value. The structures of complexes $7 \mathbf{a}$ and $\mathbf{7 b}$ reveal slightly shorter Rh1-C(NHC) bond lengths than in imidazol-2ylidene/phosphane complex 9a, as well as in a related complex described by Field et al. [2.064(2) $\AA]^{[20]}$.
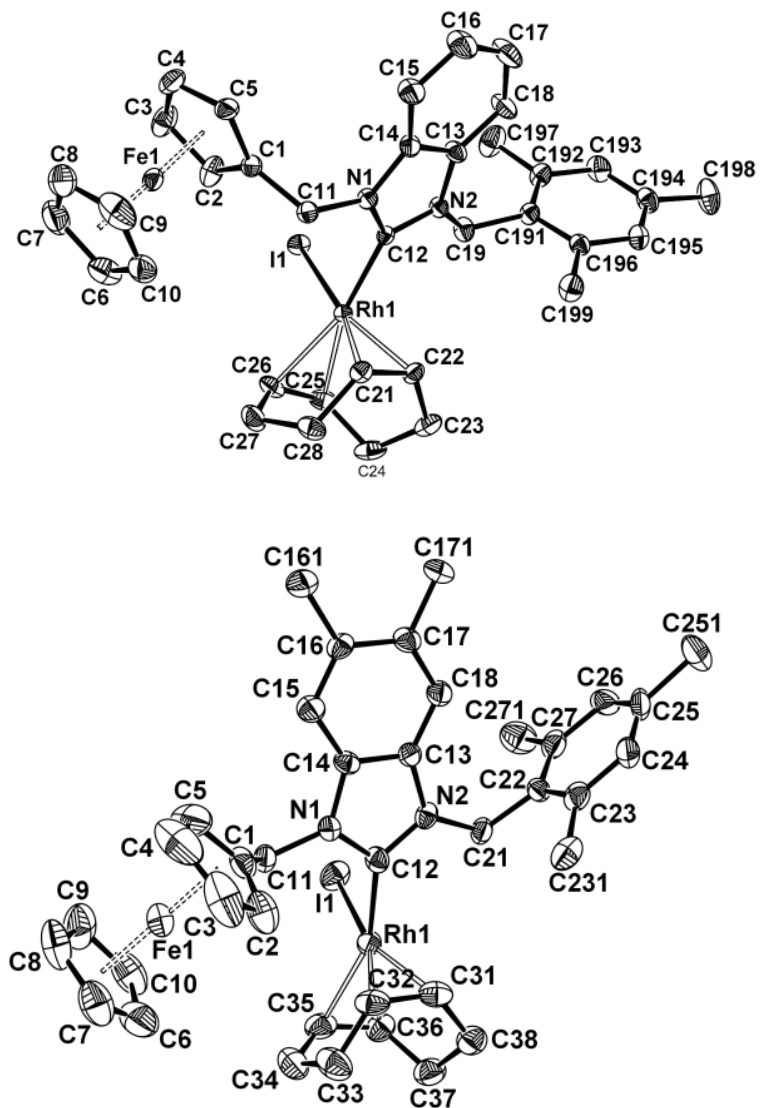

Figure 4. ORTEP views of $\mathbf{8 a}$ (top) and $\mathbf{8 b}$ (bottom). Ellipsoids are shown at the $50 \%(\mathbf{8 a})$ or $30 \%(\mathbf{8 b})$ probability level.All hydrogen atoms are omitted for clarity.

However, this difference is not observed with neutral complexes 8a and 8b: the Rh1-C(NHC) bond lengths are in the typical range observed for NHC-Rh complexes with iodide coordination. ${ }^{[8,9,21]}$ There is no evidence for a structural effect of the methyl groups in positions 5 and 6 of the benzene ring (complexes $\mathbf{7 b}$ and $\mathbf{8 b}$ ), as we can not observe any significant variation in the Rh1-C(NHC) bond lengths related to this parameter. The mesityl group is found roughly orthogonal to the benzimidazole backbone, with dihedral angles ranging from 86 to $90^{\circ}$, to limit steric interactions. 
Table 1. Selected bond lengths $(\AA)$ and bond angles $\left(^{\circ}\right)$ for complexes $\mathbf{7 , 8}$ and $\mathbf{9 a}$.

\begin{tabular}{|c|c|c|c|c|c|}
\hline & $7 a$ & $7 \mathrm{~b}$ & $9 \mathbf{a}^{[a]}$ & $8 \mathbf{a}$ & $8 \mathbf{b}$ \\
\hline \multicolumn{6}{|l|}{ Bond lengths $(\AA)$} \\
\hline Rh1-C(NHC) & $2.018(7)$ & $2.031(5)$ & $2.047(3)$ & $2.012(2)$ & $1.993(10)$ \\
\hline Rh1-P1 & $2.3138(18)$ & $2.3233(12)$ & $2.3345(8)$ & - & - \\
\hline Rh1-I1 & - & - & - & $2.6848(3)$ & $2.6784(11)$ \\
\hline \multirow{4}{*}{ Rh1-C(COD) } & $2.180(7)$ & $2.209(5)$ & $2.215(3)$ & $2.143(2)$ & $2.100(10)$ \\
\hline & $2.181(7)$ & $2.209(5)$ & $2.231(3)$ & $2.109(2)$ & $2.091(11)$ \\
\hline & $2.209(7)$ & $2.239(4)$ & $2.220(3)$ & $2.234(2)$ & $2.187(10)$ \\
\hline & $2.248(7)$ & $2.229(4)$ & $2.217(3)$ & $2.204(2)$ & $2.226(10)$ \\
\hline N1-C(NHC) & $1.355(8)$ & $1.367(5)$ & $1.359(4)$ & $1.366(3)$ & $1.364(11)$ \\
\hline N2-C(NHC) & $1.362(8)$ & $1.373(6)$ & $1.357(4)$ & $1.360(3)$ & $1.382(11)$ \\
\hline \multicolumn{6}{|l|}{ Bond angles $\left({ }^{\circ}\right)$} \\
\hline N1-C(NHC)-N2 & $105.5(6)$ & $105.2(4)$ & $104.5(2)$ & $106.02(18)$ & $104.7(8)$ \\
\hline $\mathrm{C}(\mathrm{NHC})-\mathrm{Rh} 1-\mathrm{P} 1$ & $92.06(18)$ & 93.78 (12) & $90.83(8)$ & - & - \\
\hline C(NHC)-Rh1-I1 & - & - & - & $89.57(6)$ & $86.1(3)$ \\
\hline
\end{tabular}

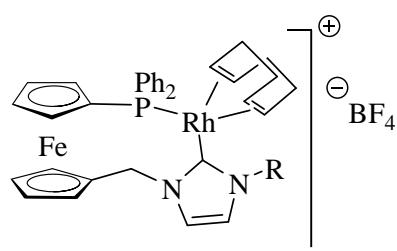

$\underline{9}$

a: $\mathrm{R}=\mathrm{Me}$

b: $\mathrm{R}=$ 2,4,6-trimethylphenyl

Figure 5. Previously described $\mathrm{Rh}^{\mathrm{I}}$ complexes with an imidazol-2-ylidene moiety. ${ }^{[4]}$

\section{(c) Catalytic hydrosilylation of methyl aryl ketones}

The catalytic activity of NHC complexes $\mathbf{7}$ and $\mathbf{8}$ was evaluated in the hydrosilylation of carbonyl compounds. ${ }^{[22,23]}$ The reactions were typically carried out with $2 \mathrm{~mol} \%$ of catalyst, in THF at room temperature (Scheme 4, Table 2). The conversion of acetophenone was followed by TLC and the crude mixture was analysed by ${ }^{1} \mathrm{H}$ NMR.

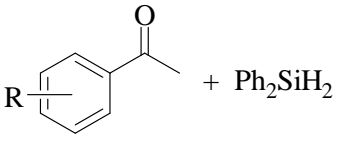<smiles>COc1ccc(C(C)O)cc1</smiles>

Scheme 4. Hydrosilylation of acetophenone and its derivatives with $\mathrm{Rh}^{1}$ complexes.

In our first attempts, we were pleased to note that all complexes were active (entries 1-2 and 6-7), although a reaction time of $20 \mathrm{~h}$ was needed to obtain reasonable yields. The yields of alcohol were much higher in the case of bifunctional, cationic complexes $\mathbf{7 a}, \mathbf{b}$. As observed in some of our previous work, the concentration of acetophenone in the medium can alter dramatically the reaction rate. ${ }^{[5]}$ We thus carried out the next catalytic tests with a more concentrated medium ( $2 \mathrm{M}$ instead of $1 \mathrm{M})$. The results were very encouraging, since we obtained a nearly quantitative yield of alcohol in $2 \mathrm{~h}$ with complex $\mathbf{7 b}$ (entry 4 ). $20 \mathrm{~h}$ were still needed with complex 7a to reach $80 \%$ conversion of the ketone (entry 3 ), probably due to the poor solubility of the catalyst in THF. In comparison, our previously described complexes 9a and 9b were poorly active, ${ }^{[4]}$ even at this concentration, as the reactions were not complete after 5 days at room temperature (entries 14 and 15).

However, increasing the concentration did not improve the yield in the case of neutral complexes $\mathbf{8 a}, \mathbf{b}$ (entries 8 and 9). In order to have a better comparison with cationic complexes $7 \mathbf{a}$ and $\mathbf{b}$, one equivalent of $\mathrm{AgBF}_{4}$ was added to compounds $\mathbf{8 a}$ and $\mathbf{b}$ to give, respectively, cationic complexes $\mathbf{1 0 a}$ and $\mathbf{1 0 b}$ (Scheme 5), where the $\mathrm{Rh}(\mathrm{I})$ centre is probably coordinated by one THF molecule in order to achieve the preferred square planar configuration. These complexes were not isolated but used directly for catalytic reactions.

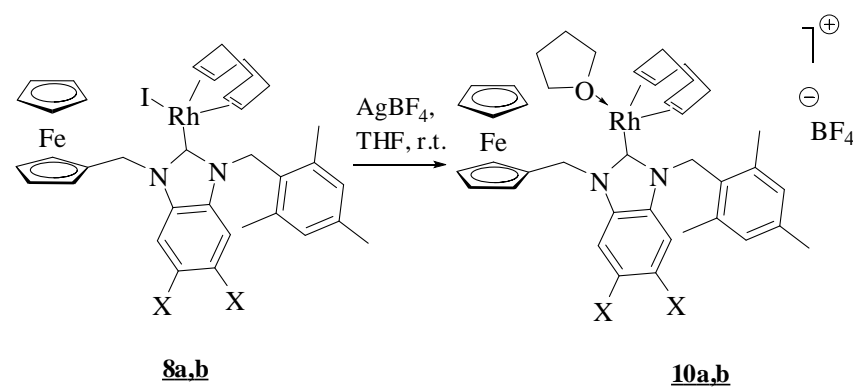

Scheme 5. Generation of cationic $\mathrm{Rh}^{\mathrm{I}}$ complexes bearing monodentate NHC ligands.

Both complexes were completely soluble in THF, in contrast to their neutral precursors. It has been reported in some other cases that the use of $\mathrm{AgX}\left(\mathrm{X}=\mathrm{OSO}_{2} \mathrm{CF}_{3}, \mathrm{BF}_{4}, \mathrm{PF}_{6}\right)$ was required in order to improve the catalytic activity, ${ }^{[23-25]}$ and this proved to be the case also with our systems. Indeed, the conversion of acetophenone was complete after only $2 \mathrm{~h}$, as shown by the ${ }^{1} \mathrm{H}$ NMR spectra of the reaction mixture before hydrolysis of the silyl ether (entries 10 and 11). However, the NMR yields calculated after hydrolysis were rather low and hardly reproducible, showing a lack of selectivity of these systems for the formation of the expected alcohol. The ${ }^{1} \mathrm{H}$ NMR spectra of the reaction mixtures before hydrolysis suggest the formation of a silyl enol ether as by-product (Scheme 6), which would then be reconverted to acetophenone by the hydrolysis step.

Indeed, the ${ }^{1} \mathrm{H}$ NMR spectra before hydrolysis show two doublets at 4.65 and $5.05 \mathrm{ppm}\left(=\mathrm{CH}_{2}, J=2.4 \mathrm{~Hz}\right)$, characteristic of 
Table 2. Hydrosilylation of acetophenone $(\mathrm{R}=\mathrm{H}){ }^{[\mathrm{a}]}$

\begin{tabular}{llllllll}
\hline Entry & $\begin{array}{l}\text { Catalyst } \\
(\mathrm{mol} \%)\end{array}$ & Additive & $\begin{array}{c}\text { Concentration } \\
(\mathrm{M})\end{array}$ & $\mathrm{t}(\mathrm{h})$ & $\begin{array}{c}\text { Conversion } \\
(\%)^{\mathrm{bb}]}\end{array}$ & $\begin{array}{c}\text { Ratio } \\
\left.\text { silyl ether/silyl enol ether }{ }^{[\mathrm{b}]}\right]\end{array}$ & $\begin{array}{c}\text { Yield of 1- } \\
\text { phenylethanol } \\
(\%)^{[\mathrm{c}]}\end{array}$ \\
\hline 1 & $\mathbf{7 a}(2)$ & - & 1 & 20 & $\mathrm{n} / \mathrm{c}$ & $\mathrm{n} / \mathrm{c}$ & 73 \\
2 & $\mathbf{7 b}(2)$ & - & 1 & 20 & $\mathrm{n} / \mathrm{c}$ & $\mathrm{n} / \mathrm{c}$ & 85 \\
3 & $\mathbf{7 a}(2)$ & - & 2 & 20 & 80 & $96: 4$ & $78^{[\mathrm{d}]}$ \\
4 & $\mathbf{7 b}(2)$ & - & 2 & 2 & 100 & $98: 2$ & 98 \\
5 & $\mathbf{7 b}(1)$ & - & 2 & 2 & 100 & $96: 4$ & 95 \\
6 & $\mathbf{8 a}(2)$ & - & 1 & 20 & $\mathrm{n} / \mathrm{c}$ & $\mathrm{n} / \mathrm{c}$ & $43^{[\mathrm{d}]}$ \\
7 & $\mathbf{8 b}(2)$ & - & 1 & 20 & $\mathrm{n} / \mathrm{c}$ & $\mathrm{n} / \mathrm{c}$ & 23 \\
8 & $\mathbf{8 a}(2)$ & - & 2 & 8 & $\mathrm{n} / \mathrm{c}$ & $\mathrm{n} / \mathrm{c}$ & $49^{[\mathrm{d}]}$ \\
9 & $\mathbf{8 b}(2)$ & - & 2 & 8 & $\mathrm{n} / \mathrm{c}$ & $\mathrm{n} / \mathrm{c}$ & 32 \\
10 & $\mathbf{1 0 a}(2)$ & - & 2 & 2 & 100 & $\mathrm{n} / \mathrm{c} ; 50: 50 ; 59: 41^{[\mathrm{c}]}$ & $62 ; 46 ; 60^{[\mathrm{ec}]}$ \\
11 & $\mathbf{1 0 b}(2)$ & - & 2 & 2 & 100 & $\mathrm{n} / \mathrm{c} ; 69: 31 ; 58: 42{ }^{[\mathrm{ec}]}$ & $83 ; 66 ; 58^{[\mathrm{e}]}$ \\
12 & $\mathbf{1 0 a}(2)$ & $\mathrm{PPh}_{3}(1$ eq. $)$ & 2 & 20 & 100 & $78: 22$ & $76^{[\mathrm{d}]}$ \\
13 & $\mathbf{1 0 b}(2)$ & $\mathrm{PPh}_{3}(1$ eq. $)$ & 2 & 2 & 100 & $87: 13$ & 84 \\
$14^{\mathrm{f}}$ & $\mathbf{9 a}(2)$ & - & 2 & 5 days & 63 & $>99: 1$ & $63^{[\mathrm{d}]}$ \\
$15^{\mathrm{f}}$ & $\mathbf{9 b}(2)$ & - & 2 & 5 days & 90 & $99: 1$ & $87^{[\mathrm{d}]}$ \\
\hline
\end{tabular}

[a] Ketone ( 1 eq.), diphenylsilane (1.1 eq.), room temperature, THF, then hydrolysis with $\mathrm{MeOH} / \mathrm{HCl}$. [b] Determined by ${ }^{1} \mathrm{H}$ NMR signal integration of the crude reaction mixture before hydrolysis, $\mathrm{n} / \mathrm{c}=$ not calculated. [c] Determined by ${ }^{1} \mathrm{H}$ NMR signal integration of the crude reaction mixture after hydrolysis. [d] Catalyst only partially soluble in THF. [e] Results of three runs. [f] Data from ref. ${ }^{[4]}$.

the silyl enol ether (the doublet at $5.05 \mathrm{ppm}$, however, is often hidden by the $\mathrm{Si}-H$ singlet of $\mathrm{Ph}_{2} \mathrm{SiH}_{2}$, showing at $5.06 \mathrm{ppm}$ ). These signals are absent from the ${ }^{1} \mathrm{H}$ spectra of the mixtures after hydrolysis, whereas two new signals, typical of acetophenone, appear at $2.6 \mathrm{ppm}\left(\mathrm{CH}_{3}, \mathrm{~s}\right)$ and $8.0 \mathrm{ppm}(\mathrm{Ar}-\mathrm{H}, \mathrm{d}, \mathrm{J}=7.5 \mathrm{~Hz})$. This process is frequently observed in ketone hydrosilylation. ${ }^{[26]}$

In order to see whether the phosphane was necessary to maintain a good selectivity, we added 1 equivalent of triphenylphosphane to complexes 10a and $\mathbf{1 0 b}$ prior to the reaction (entries 12 and 13). The reaction was complete after $2 \mathrm{~h}$ with complex $\mathbf{1 0 b}$, but needed $20 \mathrm{~h}$ with complex 10a, as the addition of $\mathrm{PPh}_{3}$ decreased the solubility of the complex in THF. The analysis of the reaction mixture before and after hydrolysis showed a selectivity increase in both cases, which confirmed our hypothesis. However, the selectivity was lower than that reached with complexes $\mathbf{7 a}$ and $\mathbf{7 b}$, showing clearly that the chelating effect is beneficial for the reaction selectivity.

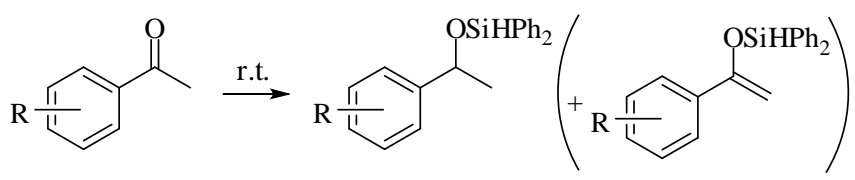

$+\mathrm{Ph}_{2} \mathrm{SiH}_{2}$

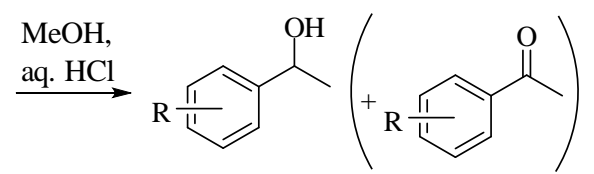

Scheme 6. Side-products generated during hydrosilylation reactions.

Encouraged by the results obtained with complex $\mathbf{7 b}$, we decided to lower the catalyst loading to $1 \mathrm{~mol} \%$ (entry 5), and were pleased to observe that the activity was preserved, with a total conversion and $95 \%$ yield in only $2 \mathrm{~h}$. Catalytic tests with acetophenone derivatives allowed us to determine the efficiency of complexes $\mathbf{7 a}$ and $7 \mathbf{b}(2 \mathrm{~mol} \%)$ with a variation of electronic or steric properties (Scheme 4, Table 3). Whereas marked differences were observed with complex $\mathbf{7 a}$, catalyst $\mathbf{7 b}$ showed a very high activity whatever the substituents of acetophenone. Indeed, even the presence of an ortho substituent did not lower the yield (entry 6).

The higher catalytic activity observed at higher ketone concentration agrees with previous reports of a saturation effect: the reaction was found first order in ketone at low concentrations, but eventually became [ketone] independent at high concentrations. ${ }^{[27-29]}$ The mechanism of this catalytic process has been addressed by many authors. Although a few variations have been discussed, the most commonly accepted mechanism remains the originally proposed one, ${ }^{[27,30-32]}$ which is based on a rate determining $\mathrm{Si}-\mathrm{H}$ oxidative addition process, yielding a $\mathrm{Rh}^{\mathrm{III}}$ silyl hydride intermediate. This step would be followed by ketone coordination, insertion into the metal-silyl bond, and final reductive elimination. Interestingly, the observation by Kolb and Hetflejs of a saturation effect (while working with a cationic system) was interpreted as indicating reversible complexation of the ketone prior to the rate determining silane addition, ${ }^{[28]}$ but Giering later discarded this variant when he could properly model, on the basis of the other mechanism, kinetic results that he obtained with a neutral system, which also included a saturation effect in [ketone]. ${ }^{[27]}$ However, the data fittings were described as unsatisfactory unless additional processes of catalyst decomposition were included at various places in the catalytic cycle. We believe that the interpretation offered by Kolb and Hetflejs is reasonable and probably applies to our system, for the following reasons. The COD ligand is probably lost rapidly from the coordination sphere by hydrosilylation or hydrogenation processes, as also observed or proposed in other cases. ${ }^{[27,32-34]}$ The resulting $\left[\left(\mathrm{NHCFCPPh}_{2}\right) \mathrm{Rh}\right]^{+}$system is then likely coordinated by two solvent molecules, but the lability of these should easily allow ketone coordination, faster than the rate-determining silane oxidative addition. Thus, the rate-determining silane oxidative addition may preferentially occur on the ketone substituted complex, as shown in Scheme 7, when the ketone concentration is high, whereas the order of events may be inverted (pathway indicated with dashed arrows in Scheme 7) at low ketone concentrations. 


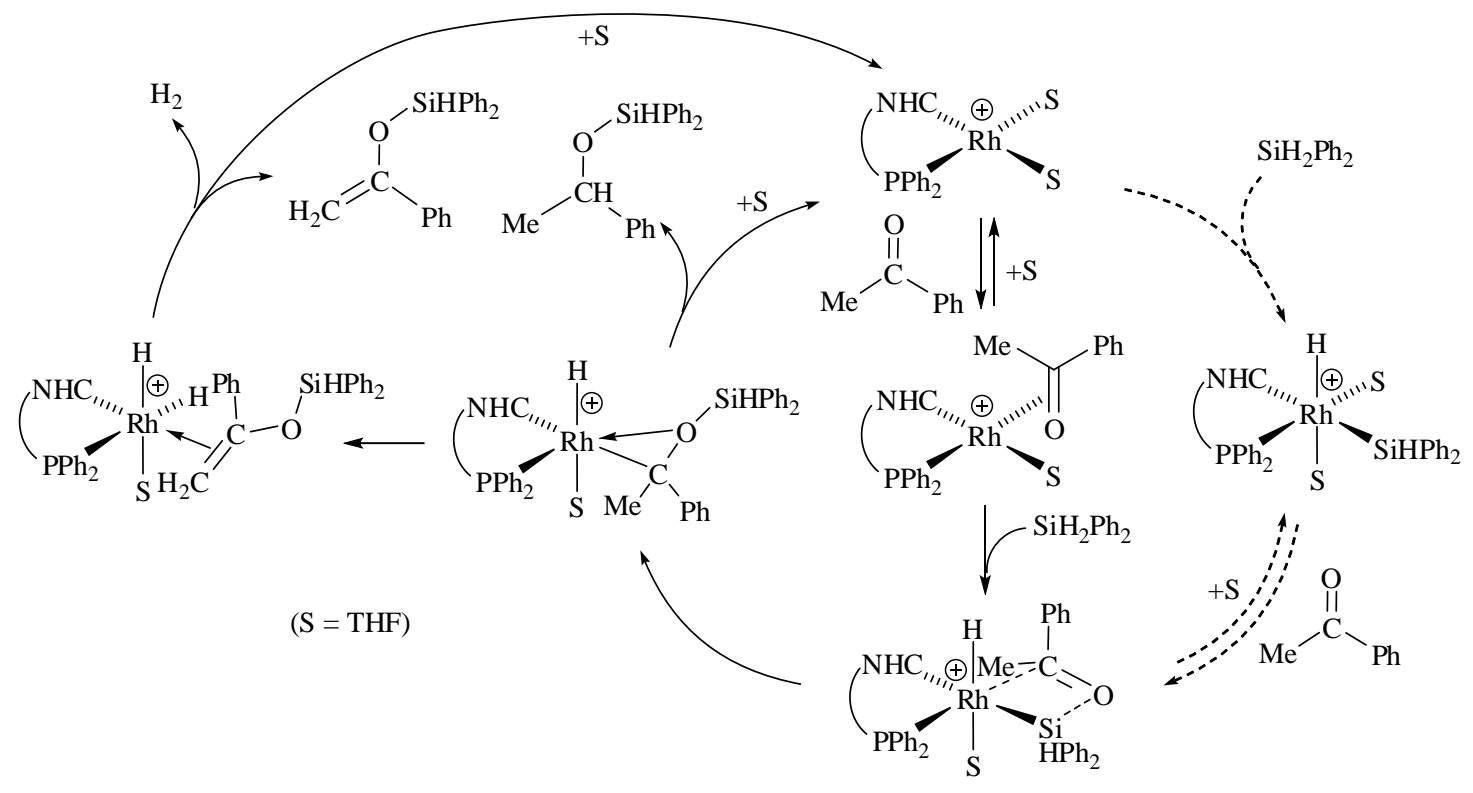

Scheme 7. Proposed mechanism for the formation of saturated and unsaturated hydrosilylation products.

Finally, the formation of the unsaturated silyl ether can be easily rationalized on the basis of a competition between the reductive elimination of the hydrosilylation product and a $\beta-\mathrm{H}$ elimination step from a common intermediate (Scheme 7). Although the mechanism of ketone hydrosilylation is not as well established as that of olefin hydrosilylation, ${ }^{[35]}$ there is good evidence supporting a ketone insertion into the $\mathrm{Rh}-\mathrm{Si}$ bond followed by $\mathrm{C}-\mathrm{H}$ reductive elimination, rather than the alternative insertion into the $\mathrm{Rh}-\mathrm{H}$ bond followed by $\mathrm{Si}-\mathrm{C}$ reductive elimination. ${ }^{[24,36]}$ Supposedly, the absence of the phosphane ligand renders the $\beta-\mathrm{H}$ elimination pathway more easily accessible through the availability of an additional open coordination site.

\section{Conclusions}

In conclusion, the benzimidazol-2-ylidene unit gives highly active hydrosilylation rhodium catalysts, proving superior to the imidazol-2-ylidene. Moreover, bidentate NHC ligands bearing a phosphanyl group ensure a much better selectivity in the desired product than monodentate NHC ligands. The introduction of methyl substituents on the benzene ring of the benzimidazol-2ylidene ligand enhanced the solubility of the rhodium complex in the reaction medium. This work was carried out with achiral ligands, and we are now planning to prepare planar chiral 1,2disubstituted ferrocenyl ligands, using the methodology developed here, for applications to asymmetric hydrosilylation.

\section{Experimental Section}

All reactions were carried out under a dry argon atmosphere using Schlenk glassware and vacuum line techniques. Solvents for syntheses were dried and degassed by standard methods before use. Spectra were recorded on Brüker ARX250, AV300 or DPX300 spectrometers. All spectra were recorded in $\mathrm{CDCl}_{3}$, unless otherwise stated. Mass spectra were obtained from acetonitrile solutions on a TSQ7000 instrument from ThermoElectron. (1'-diphenylthiophosphinoferrocen-1-yl)methanol $\mathbf{1}$ was prepared according to our previsouly published procedure. ${ }^{[37]}[\mathrm{Rh}(\mathrm{OMe})(\mathrm{COD})]_{2}{ }^{[38]}$, $\mathbf{2 a}$ and $\mathbf{2} \mathbf{b}^{[7]}$ and $\mathbf{3}^{[39]}$ were prepared according to literature procedures.

Benzimidazolium salt 4a: To a solution of ferrocenyl alcohol 1 (100 mg, $0.23 \mathrm{mmol})$ in degassed dichloromethane $(5 \mathrm{~mL})$ was quickly added $\mathrm{HBF}_{4}$
(35 $\mu \mathrm{L}, 54 \mu \mathrm{wt} \%$ in $\left.\mathrm{Et}_{2} \mathrm{O}\right)$, immediately followed by $N$-(2,4,6trimethylbenzyl) benzimidazole $2 \mathbf{a}(86 \mathrm{mg}, 0.35 \mathrm{mmol})$. The mixture was washed with $2 \mathrm{M}$ aq. $\mathrm{HCl}$, water, satd. aq. $\mathrm{NaHCO}_{3}$ and water again. The organic phase was dried $\left(\mathrm{MgSO}_{4}\right)$, filtered and concentrated in vacuo. The residue was purified by column chromatography on silica gel (eluent: $\mathrm{CH}_{2} \mathrm{Cl}_{2}$ /acetone 9:1) to give a yellow-orange solid (121 mg, 70\% yield). $\mathrm{C}_{40} \mathrm{H}_{38} \mathrm{BF}_{4} \mathrm{FeN}_{2} \mathrm{PS}$ (752.1): Calcd: C 63.82, H 5.05, N 3.72; found: C 63.60, $\mathrm{H}$ 5.32, N 3.64. ${ }^{1} \mathrm{H}$ NMR $\left(300 \mathrm{MHz}, \mathrm{CDCl}_{3}, 25^{\circ} \mathrm{C}\right): \delta=9.30(\mathrm{~s}, 1 \mathrm{H}$, $\left.\mathrm{NCHN}^{+}\right), 7.98\left(\mathrm{~d}, J_{\mathrm{H}, \mathrm{H}}=8.4 \mathrm{~Hz}, 1 \mathrm{H}\right.$, benzimidazole $), 7.29\left(\mathrm{~d}, J_{\mathrm{H}, \mathrm{H}}=8.4 \mathrm{~Hz}\right.$, 1H, benzimidazole) 7.43-7.67 (m, 12H, benzimidazole $+\mathrm{ArH}), 6.98(\mathrm{~s}, 2 \mathrm{H}$, Mes), 5.61 (s, 2H, CH -Mes), 5.50 (s, 2H, $\mathrm{CH}_{2}$-Fc), 4.75, 4.71, 4.48, 4.08 (t, $\left.J_{\mathrm{H}, \mathrm{H}}=.1 .8 \mathrm{~Hz}, 8 \mathrm{H}, \mathrm{Cp}\right), 2.33\left(\mathrm{~s}, 3 \mathrm{H}, p-\mathrm{CH}_{3} \mathrm{Mes}\right) 2.26$ (s, 6H, o-CH $\mathrm{CH}_{3} \mathrm{Mes}$ ). ${ }^{13} \mathrm{C}\left\{{ }^{1} \mathrm{H}\right\}$ NMR $\left(75.5 \mathrm{MHz}, \mathrm{CDCl}_{3}, 25{ }^{\circ} \mathrm{C}\right): \delta=141.32\left(\mathrm{NCN}^{+}\right), 140.20$, $137.93,134.55,133.39,131.69,131.55,131.49,131.41,128.49,128.33$, 127.26, 124.32, 113.89, 113.41 (Ar-C), 130.31 (Mes), 80.73, 74.31, 74.15, 73.47, 73.33, 72.06, $70.91(\mathrm{Cp}), 47.01\left(\mathrm{CH}_{2}-\mathrm{Mes}\right), 46.98\left(\mathrm{CH}_{2}-\mathrm{Fc}\right), 21.09$ (p- $\left.\mathrm{CH}_{3} \mathrm{Mes}\right), 19.84$ (o- $\left.\mathrm{CH}_{3} \mathrm{Mes}\right) .{ }^{31} \mathrm{P}\left\{{ }^{1} \mathrm{H}\right\} \mathrm{NMR}\left(121.5 \mathrm{MHz}, \mathrm{CDCl}_{3}, 25\right.$ $\left.{ }^{\circ} \mathrm{C}\right): \delta=41.6$.

Benzimidazolium salt 4b: To a solution of ferrocenyl alcohol 1 (100 mg, $0.23 \mathrm{mmol}$ ) in degassed dichloromethane $(5 \mathrm{~mL})$ was quickly added $\mathrm{HBF}_{4}$ (35 $\mu \mathrm{L}, 54 \mathrm{wt} \%$ in $\left.\mathrm{Et}_{2} \mathrm{O}\right)$, immediately followed by $N$-(2,4,6trimethylbenzyl)-5,6-dimethyl benzimidazole $\mathbf{2 b}$ (96 $\mathrm{mg}, 0.35 \mathrm{mmol}$ ). The mixture was washed with $2 \mathrm{M}$ aq. $\mathrm{HCl}$, water, satd. aq. $\mathrm{NaHCO}_{3}$ and water again. The organic phase was dried $\left(\mathrm{MgSO}_{4}\right)$, filtered and concentrated in vacuo. The residue was purified by column chromatography on silica gel (eluent: $\mathrm{CH}_{2} \mathrm{Cl}_{2} /$ acetone 9:1) to give a yellow-orange solid (108 mg, 60\% yield). $\mathrm{C}_{42} \mathrm{H}_{42} \mathrm{BF}_{4} \mathrm{FeN}_{2} \mathrm{PS}$ (780.1): Calcd: $\mathrm{C} 64.61, \mathrm{H}$ 5.38, N 3.59; found: $\mathrm{C}$ 64.67, H 5.82, N 3.85. ${ }^{1} \mathrm{H}$ NMR (300 $\left.\mathrm{MHz}, \mathrm{CDCl}_{3}, 25^{\circ} \mathrm{C}\right): \delta=9.01(\mathrm{~s}, 1 \mathrm{H}$, $\left.\mathrm{NCHN}^{+}\right), 7.78-7.70(\mathrm{~m}, 3 \mathrm{H}), 7.58(\mathrm{~s}, 1 \mathrm{H}), 7.51-7.45(\mathrm{~m}, 5 \mathrm{H}), 7.31(\mathrm{~s}, 1 \mathrm{H})$, $7.26(\mathrm{~s}, 1 \mathrm{H}), 7.10(\mathrm{~s}, 1 \mathrm{H})$ (benzimidazole $+\mathrm{Ar}-H), 6.99$ (s, 2H, Mes), 5.51, 5.39 (s, 2H, CH$\left.H_{2}-\mathrm{Mes}\right), 5.32,5.21\left(\mathrm{~s}, 2 \mathrm{H}, \mathrm{CH}_{2}-\mathrm{Fc}\right), 4.74$, (t, $J_{\mathrm{H}, \mathrm{H}}=1.8 \mathrm{~Hz}$, $1 \mathrm{H}, \mathrm{Cp}), 4.66\left(\mathrm{t}, J_{\mathrm{H}, \mathrm{H}}=1.8 \mathrm{~Hz}, 1 \mathrm{H}, \mathrm{Cp}\right), 4.55\left(\mathrm{~d}, J_{\mathrm{H}, \mathrm{H}}=1.8 \mathrm{~Hz}, 2 \mathrm{H}, \mathrm{Cp}\right)$, 4.48-4.47 (m, 1H, Cp), 4.30 (s, 1H, Cp), 4.07 (t, $\left.J_{\mathrm{H}, \mathrm{H}}=1.8 \mathrm{~Hz}, 1 \mathrm{H}, \mathrm{Cp}\right)$, 4.00 (s, 1H, Cp), 2.49, 2.44, 2.41 (s, 6H,o-CH $\left.\mathrm{CH}_{3} \mathrm{Mes}\right), 2.33\left(\mathrm{t}, J_{\mathrm{H}, \mathrm{H}}=.3 \mathrm{~Hz}\right.$, $\left.3 \mathrm{H}, p-\mathrm{CH}_{3} \mathrm{Mes}\right), 2.26\left(\mathrm{~d}, J_{\mathrm{H}, \mathrm{H}}=1.2 \mathrm{~Hz}, 6 \mathrm{H}, \mathrm{CH}\right.$ benzimidazole $) .{ }^{13} \mathrm{C}\left\{{ }^{1} \mathrm{H}\right\}$ $\mathrm{NMR}\left(75.5 \mathrm{MHz}, \mathrm{CDCl}_{3}, 25{ }^{\circ} \mathrm{C}\right): \delta=139.71\left(\mathrm{NCN}^{+}\right), 137.92,137.87$, $137.54,137.42,133.46,131.69,131.54,131.40,131.36,128.48,128.36$, 128.32, 128.20, 124.49, 120.31, 113.51, 112.89, 109.77 (Ar-C), 130.22 (Mes), 81.01, 74.28, 74.11, 73.46, 73.33, 72.18, 72.05, 71.93, 70.84, 69.29, 69.22, $60.10(\mathrm{Cp}), 46.66,46.49\left(\mathrm{CH}_{2}-\mathrm{Mes}\right), 43.03\left(\mathrm{CH}_{2}-\mathrm{Fc}\right), 21.08,21.04$ 
$\left(o-\mathrm{CH}_{3}\right.$ Mes $), 20.78,20.65,20.29\left(p-\mathrm{CH}_{3} \mathrm{Mes}\right), 19.78,19.56\left(\mathrm{CH}_{3}\right.$ benzimidazole). ${ }^{31} \mathrm{P}\left\{{ }^{1} \mathrm{H}\right\}$ NMR $\left(121.5 \mathrm{MHz}, \mathrm{CDCl}_{3}, 25^{\circ} \mathrm{C}\right): \delta=41.5$.

Benzimidazolium salt 5a: Raney Nickel ( $2.2 \mathrm{~g}$, suspension in water) was washed with degassed methanol $(3 \times 10 \mathrm{~mL})$, degassed diethyl ether $(3 \times 10$ $\mathrm{mL})$ and finally degassed acetonitrile $(3 \times 10 \mathrm{~mL})$. A solution of $4 \mathbf{a}(500 \mathrm{mg}$, $0.67 \mathrm{mmol})$ in acetonitrile $(10 \mathrm{~mL})$ was added; the mixture was stirred at room temperature for $24 \mathrm{~h}$, filtered on a short path of Celite ${ }^{\circledR}$ and rinsed with acetonitrile. The solution was concentrated and the orange solid was dried in vacuo ( $420 \mathrm{mg}, 87 \%$ yield). $\mathrm{C}_{40} \mathrm{H}_{38} \mathrm{BF}_{4} \mathrm{FeN}_{2} \mathrm{P}$ (720.1): Calcd: $\mathrm{C}$ 66.66, H 5.28, N 3.89; found: C 65.01, H 5.99, N 3.92. ${ }^{1} \mathrm{H}$ NMR (300 MHz, $\left.\mathrm{CDCl}_{3}, 25{ }^{\circ} \mathrm{C}\right): \delta=9.10\left(\mathrm{~s}, \quad 1 \mathrm{H}, \quad \mathrm{NCH \textrm {N } ^ { + }}\right), 7.70-7.32(\mathrm{~m}, \quad 12 \mathrm{H}$, benzimidazole $+\mathrm{Ar}-H), 6.96$ (s, 2H, Mes), 5.60 (s, 2H, $\mathrm{CH}_{2}$-Mes), 5.15 (s, $\left.2 \mathrm{H}, \mathrm{CH}_{2}-\mathrm{Fc}\right), 4.58,4.36,4.22,4.13\left(\mathrm{t}, J_{\mathrm{H}, \mathrm{H}}=1.8 \mathrm{~Hz}, 8 \mathrm{H}, \mathrm{Cp}\right), 2.32(\mathrm{~s}, 3 \mathrm{H}$, $p$ - $\mathrm{CH}_{3} \mathrm{Mes}$ ), 2.25 (s, $6 \mathrm{H}, o$-CH $\left.\mathrm{CH}_{3} \mathrm{Mes}\right) .{ }^{13} \mathrm{C}\left\{{ }^{1} \mathrm{H}\right\} \mathrm{NMR}\left(75.5 \mathrm{MHz}, \mathrm{CDCl}_{3}\right.$, $\left.25^{\circ} \mathrm{C}\right): \delta=141.20\left(\mathrm{NCN}^{+}\right), 140.14,138.00,133.64,131.52,131.33,129.62$, 128.89, 128.30, 127.22, 127.04, 124.49, 113.60, 113.53 (Ar-C), 130.26 (Mes), 79.54, 72.56, 70.73, $70.45(\mathrm{Cp}), 47.31\left(\mathrm{CH}_{2}-\mathrm{Mes}\right), 46.91\left(\mathrm{CH}_{2}-\mathrm{Fc}\right)$, 21.07 (p-CH $\left.\mathrm{CH}_{3} \mathrm{Mes}\right), 19.85$ (o- $\left.\mathrm{CH}_{3} \mathrm{Mes}\right) .{ }^{31} \mathrm{P}\left\{{ }^{1} \mathrm{H}\right\} \mathrm{NMR}\left(121.5 \mathrm{MHz}, \mathrm{CDCl}_{3}\right.$, $\left.25^{\circ} \mathrm{C}\right): \delta=-17.2$.

Benzimidazolium salt 5b: Raney Nickel ( $2.4 \mathrm{~g}$, suspension in water) was washed with degassed methanol $(3 \times 10 \mathrm{~mL})$, degassed diethyl ether $(3 \times 10$ $\mathrm{mL})$ and finally degassed acetonitrile $(3 \times 10 \mathrm{~mL})$. A solution of $\mathbf{4 b}(450 \mathrm{mg}$, $0.58 \mathrm{mmol})$ in acetonitrile $(10 \mathrm{~mL})$ was added; the mixture was stirred at room temperature for $24 \mathrm{~h}$, filtered on a short path of Celite ${ }^{\circledR}$ and rinsed with acetonitrile. The solution was concentrated and the orange solid was dried in vacuo ( $370 \mathrm{mg}, 85 \%$ yield). $\mathrm{C}_{42} \mathrm{H}_{42} \mathrm{BF}_{4} \mathrm{FeN}_{2} \mathrm{P}$ (748.1): Calcd: $\mathrm{C}$ 67.37, H 5.61, N 3.74; found: C 67.23, H 5.62, N 3.88. ${ }^{1} \mathrm{H}$ NMR (300 MHz, $\left.\mathrm{CDCl}_{3}, 25^{\circ} \mathrm{C}\right): \delta=8.86\left(\mathrm{~s}, 1 \mathrm{H}, \mathrm{NCHN}^{+}\right), 7.59(\mathrm{~s}, 1 \mathrm{H}), 7.41-7.32(\mathrm{~m}, 8 \mathrm{H})$, $7.31(\mathrm{~s}, 1 \mathrm{H}), 7.26(\mathrm{~s}, 1 \mathrm{H}), 7.11(\mathrm{~s}, 1 \mathrm{H})$ (benzimidazole + Ar- $H), 6.98(\mathrm{~s}, 2 \mathrm{H}$, Mes), 5.51, (s, 2H, CH$H_{2}$-Mes), 5.21, $5.07\left(\mathrm{~s}, 2 \mathrm{H}, \mathrm{CH}_{2}-\mathrm{Fc}\right), 4.58,\left(\mathrm{t}, J_{\mathrm{H}, \mathrm{H}}=\right.$ $1.8 \mathrm{~Hz}, 2 \mathrm{H}, \mathrm{Cp}), 4.41(\mathrm{~s}, 1 \mathrm{H}, \mathrm{Cp}), 4.33\left(\mathrm{t}, J_{\mathrm{H}, \mathrm{H}}=.1 .8 \mathrm{~Hz}, 2 \mathrm{H}, \mathrm{Cp}\right), 4.21(\mathrm{t}$, $\left.J_{\mathrm{H}, \mathrm{H}}=.1 .8 \mathrm{~Hz}, 1 \mathrm{H}, \mathrm{Cp}\right), 4.13\left(\mathrm{~d}, J_{\mathrm{H}, \mathrm{H}}=.1 .8 \mathrm{~Hz}, 2 \mathrm{H}, \mathrm{Cp}\right), 2.45,2.41(\mathrm{~s}, 6 \mathrm{H}, o-$ $\mathrm{CH}_{3} \mathrm{Mes}$ ), 2.35, 2.33 (s, 3H, $p$-CH $\mathrm{CH}_{3} \mathrm{Mes}$ ), 2.25 (d, $J_{\mathrm{H}, \mathrm{H}}=4.2 \mathrm{~Hz}, 6 \mathrm{H}, \mathrm{CH}_{3}$ benzimidazole). ${ }^{13} \mathrm{C}\left\{{ }^{1} \mathrm{H}\right\}$ NMR $\left(75.5 \mathrm{MHz}, \mathrm{CDCl}_{3}, 25{ }^{\circ} \mathrm{C}\right): \delta=139.66$ $\left(\mathrm{NCN}^{+}\right), 138.87,137.97,137.33,137.25,133.53,128.73,128.31,113.16$, 112.97 (Ar-C), 130.19 (Mes), 79.82, 74.10, 72.45, 70.60, 70.37, 65.85 (Cp), $47.03\left(\mathrm{CH}_{2}\right.$-Mes), $46.40\left(\mathrm{CH}_{2}-\mathrm{Fc}\right), 21.06,20.76,20.73\left(\mathrm{CH}_{3} \mathrm{Mes}\right), 19.75$ $\left(\mathrm{CH}_{3}\right.$ benzimidazole). ${ }^{31} \mathrm{P}\left\{{ }^{1} \mathrm{H}\right\} \mathrm{NMR}\left(121.5 \mathrm{MHz}, \mathrm{CDCl}_{3}, 25{ }^{\circ} \mathrm{C}\right): \delta=-17.1$. Benzimidazolium salt 6a: (Ferrocenylmethyl)trimethylammonium iodide 3 (465 mg, $1.2 \mathrm{mmol}$ ) was slowly added to a solution of $N$-(2,4,6trimethylbenzyl) benzimidazole $2 \mathrm{a}(325 \mathrm{mg}, 1.3 \mathrm{mmol})$ in acetonitrile (10 $\mathrm{mL}$ ). The mixture was heated to reflux for $48 \mathrm{~h}$ then the solvent was removed in vacuo. The residue was purified by column chromatography on silica gel (eluent: $\mathrm{CH}_{2} \mathrm{Cl}_{2} /$ acetone 8:2) to give an orange solid (485 mg, $70 \%$ yield). $\mathrm{C}_{28} \mathrm{H}_{29} \mathrm{FeIN} 2$ (578.8): Calcd: $\mathrm{C} 58.05, \mathrm{H} 5.01, \mathrm{~N} 4.84$; found: $\mathrm{C}$ 58.10, H 5.08, N 4.37. ${ }^{1} \mathrm{H}$ NMR $\left(300 \mathrm{MHz}, \mathrm{CDCl}_{3}, 25^{\circ} \mathrm{C}\right): \delta=10.60(\mathrm{~s}, 1 \mathrm{H}$ $\mathrm{NCH \textrm {N } ^ { + }}$ ), 7.77, $7.30\left(\mathrm{dd}, J_{\mathrm{H}, \mathrm{H}}=8.4 \mathrm{~Hz}, 2 \mathrm{H}\right.$, benzimidazole), 7.57, $7.48(\mathrm{dt}$ $J_{\mathrm{H}, \mathrm{H}}=6.2 \mathrm{~Hz}, 2 \mathrm{H}$, benzimidazole), $6.96(\mathrm{~s}, 2 \mathrm{H}, \mathrm{Mes}), 5.72\left(\mathrm{~s}, 2 \mathrm{H}, \mathrm{CH}_{2^{-}}\right.$ $\mathrm{Mes}), 5.32\left(\mathrm{~s}, 2 \mathrm{H}, \mathrm{CH}_{2}-\mathrm{Fc}\right), 4.55,4.31,4.23\left(\mathrm{t}, J_{\mathrm{H}, \mathrm{H}}=1.8 \mathrm{~Hz}, 9 \mathrm{H}, \mathrm{Cp}\right), 2.32$ (s, 9H, CH $\left.\mathrm{CH}_{3} \mathrm{Mes}\right) .{ }^{13} \mathrm{C}\left\{{ }^{1} \mathrm{H}\right\}$ NMR $\left(75.5 \mathrm{MHz}, \mathrm{CDCl}_{3}, 25{ }^{\circ} \mathrm{C}\right): \delta=140.96$ $\left(\mathrm{NCN}^{+}\right), 140.03,137.98,131.35\left(\mathrm{~d}, J_{\mathrm{C}, \mathrm{H}}=4.5 \mathrm{~Hz}\right), 127.22\left(\mathrm{~d}, J_{\mathrm{C}, \mathrm{H}}=10.6\right.$ $\mathrm{Hz}), 124.65,113.67$ (d, $\left.J_{\mathrm{C}, \mathrm{H}}=12.8 \mathrm{~Hz}\right),(\mathrm{Ar}-\mathrm{C}), 130.32(\mathrm{Mes}), 79.20,69.77$, 69.64, 69.55, 69.48, 69.35, $69.30(\mathrm{Cp}), 48.09\left(\mathrm{CH}_{2}-\mathrm{Mes}\right), 47.12\left(\mathrm{CH}_{2}-\mathrm{Fc}\right)$, $21.13\left(p-\mathrm{CH}_{3} \mathrm{Mes}\right), 20.44$ (d, $J_{\mathrm{C}, \mathrm{H}}=4.5 \mathrm{~Hz}, o-\mathrm{CH}_{3} \mathrm{Mes}$ ).

Benzimidazolium salt 6b: (Ferrocenylmethyl)trimethylammonium iodide 3 (465 mg, $1.2 \mathrm{mmol}$ ) was slowly added to a solution of $N$-(2,4,6trimethylbenzyl)-5,6-dimethyl benzimidazole $2 \mathbf{b}$ (361 $\mathrm{mg}, 1.3 \mathrm{mmol})$ in acetonitrile $(10 \mathrm{~mL})$. The mixture was heated to reflux for $48 \mathrm{~h}$ then the solvent was removed in vacuo. The residue was purified by column chromatography on silica gel (eluent: $\mathrm{CH}_{2} \mathrm{Cl}_{2} /$ acetone 8:2) to give an orange solid (590 mg, $81 \%$ yield). $\mathrm{C}_{30} \mathrm{H}_{33} \mathrm{FeIN}_{2}$ (606.8): Calcd: C 59.33, H 5.44, N 4.61; found: C 61.01, H 6.08, N 4.80. ${ }^{1} \mathrm{H}$ NMR $\left(300 \mathrm{MHz}, \mathrm{CDCl}_{3}\right.$, $\left.25^{\circ} \mathrm{C}\right): \delta=10.21\left(\mathrm{~s}, 1 \mathrm{H}, \mathrm{NCH \textrm {N } ^ { + }}\right), 7.11,7.27,7.32,7.50,7.59(\mathrm{~s}, 2 \mathrm{H}$, benzimidazole), 6.98 (s, 2H, Mes), 5.64 (d, $J_{\mathrm{H}, \mathrm{H}}=8.7 \mathrm{~Hz}, 2 \mathrm{H}, \mathrm{CH}_{2}$-Mes), $5.22\left(\mathrm{~s}, 2 \mathrm{H}, \mathrm{CH}_{2}-\mathrm{Fc}\right), 4.52,\left(\mathrm{t}, J_{\mathrm{H}, \mathrm{H}}=2.1 \mathrm{~Hz}, 2 \mathrm{H}, \mathrm{Cp}\right), 4.30,(\mathrm{~s}, 5 \mathrm{H}, \mathrm{Cp})$, $4.22\left(\mathrm{t}, J_{\mathrm{H}, \mathrm{H}}=2.1 \mathrm{~Hz}, 2 \mathrm{H}, \mathrm{Cp}\right), 2.43\left(\mathrm{~d}, J_{\mathrm{H}, \mathrm{H}}=10.2 \mathrm{~Hz}, 6 \mathrm{H}, o-\mathrm{CH}_{3}-\mathrm{Mes}\right)$, $2.34\left(\mathrm{~d}, J_{\mathrm{H}, \mathrm{H}}=8.1 \mathrm{~Hz}, 6 \mathrm{H}, \mathrm{CH}_{3}\right.$ benzimidazole), 2.27 (s, 3H, $\left.p-\mathrm{CH}_{3}-\mathrm{Mes}\right)$. ${ }^{13} \mathrm{C}\left\{{ }^{1} \mathrm{H}\right\}$ NMR $\left(75.5 \mathrm{MHz}, \mathrm{CDCl}_{3}, 25{ }^{\circ} \mathrm{C}\right): \delta=140.95\left(\mathrm{NCN}^{+}\right), 140.00$, 139.86, 138.72, 137.99, 137.90, 137.31, 137.26, 132.00, 130.29, 130.12, 129.97, 129.62, 127.37, 124.82, 120.35, 113.18, 113.04, 109.78, (Ar-C), 131.15 (Mes), 79.53 (Cp), 69.32 (m, Cp), 47.77, $46.59\left(\mathrm{CH}_{2}\right.$-Mes), 43.05 $\left(\mathrm{CH}_{2}-\mathrm{Fc}\right), 19.58$ ( $\left.p-\mathrm{CH}_{3} \mathrm{Mes}\right), 20.31,20.42\left(\mathrm{CH}_{3}\right.$ benzimidazole $), 20.75$, $21.92\left(o-\mathrm{CH}_{3} \mathrm{Mes}\right)$.

Rhodium complex 7a: $t$-BuOK (23.3 mg, $0.21 \mathrm{mmol})$ and $[\mathrm{Rh}(\mathrm{COD}) \mathrm{Cl}]_{2}$ $(47.6 \mathrm{mg}, 0.097 \mathrm{mmol})$ were placed in a Schlenk tube, the solids were degassed and THF $(10 \mathrm{~mL})$ was added. The solution was stirred for $30 \mathrm{~min}$ at room temperature, then slowly added to $\mathbf{5 a}(139 \mathrm{mg}, 0.194 \mathrm{mmol})$, which was precooled to $-78^{\circ} \mathrm{C}$. The mixture was stirred at $-78^{\circ} \mathrm{C}$ for 15 min then $2 \mathrm{~h}$ at room temperature. The solvent was evaporated and the residue taken up into degassed $\mathrm{CH}_{2} \mathrm{Cl}_{2}(10 \mathrm{~mL}) . \mathrm{AgBF}_{4}(56.7 \mathrm{mg}, 0.291 \mathrm{mmol})$ was added, the mixture was stirred for $30 \mathrm{~min}$ at room temperature then filtered on Celite ${ }^{\circledR}$. The solvent was evaporated in vacuo and the residue was filtered on silica gel (eluent: $\mathrm{CH}_{2} \mathrm{Cl}_{2}$ /acetone 95:5) to give 7a as an orange solid (154 mg, 86\% yield). $\mathrm{C}_{48} \mathrm{H}_{49} \mathrm{BF}_{4} \mathrm{FeN}_{2} \mathrm{PRh}$ (929.6): Calcd: $\mathrm{C} 61.96, \mathrm{H}$ 5.27, N 3.01; found: C 61.55, H 5.60, N 2.98. ${ }^{1} \mathrm{H}$ NMR (300 MHz, $\mathrm{CDCl}_{3}$, $\left.25{ }^{\circ} \mathrm{C}\right): \delta=7.51-7.30(\mathrm{~m}, 10 \mathrm{H}, \operatorname{Ar}-H), 7.62\left(\mathrm{~d}, J_{\mathrm{H}, \mathrm{H}}=8.4 \mathrm{~Hz}, 1 \mathrm{H}\right.$, benzimidazole), $7.46\left(\mathrm{~d}, J_{\mathrm{H}, \mathrm{H}}=15.3 \mathrm{~Hz}, 1 \mathrm{H}\right.$, benzimidazole $), 6.26\left(\mathrm{~d}, J_{\mathrm{H}, \mathrm{H}}=\right.$ $15.3 \mathrm{~Hz}, 1 \mathrm{H}$, benzimidazole), $5.77\left(\mathrm{~d}, J_{\mathrm{H}, \mathrm{H}}=8.4 \mathrm{~Hz}, 1 \mathrm{H}\right.$, benzimidazole), 6.93 (s, 2H, Mes), 5.47 (d, $J_{\mathrm{H}, \mathrm{H}}=15 \mathrm{~Hz}, 2 \mathrm{H}, \mathrm{CH}_{2}$-Mes), 4.97 (d, $J_{\mathrm{H}, \mathrm{H}}=15$ $\mathrm{Hz}, 2 \mathrm{H}, \mathrm{CH}_{2}-\mathrm{Fc}$ ), 4.49, 4.24, 4.11 (s, 8H, Cp), 5.18 (s, 2H, COD-CH), 4.40 (s, 2H, COD-CH), 2.53 (s, 4H, COD-CH $H_{2}$ ), 2.31 (s, 4H, COD-CH $H_{2}$ ), 2.37 (s, $6 \mathrm{H}, o-\mathrm{CH}_{3} \mathrm{Mes}$ ), 1.82 (s, $\left.3 \mathrm{H}, p-\mathrm{CH}_{3} \mathrm{Mes}\right) .{ }^{13} \mathrm{C}\left\{{ }^{1} \mathrm{H}\right\} \mathrm{NMR}(75.5 \mathrm{MHz}$, $\left.\mathrm{CDCl}_{3}, 25{ }^{\circ} \mathrm{C}\right): \delta=192.52\left(\mathrm{~d}, J_{\mathrm{Rh}, \mathrm{C}}=50.8 \mathrm{~Hz}, \mathrm{C}_{\text {carbene }}\right), 139.78,138.55$, 134.11, 131.96, 131.65, 130.92, 129.96, 128.71, 126.10, 123.65, 111.38, 110.93 (Ar-C), 129.82 (Mes), 71.26, 69.98, 69.31, 68.44 (Cp), 99.13, 96.50, 73.46 (COD-CH), 30.90, $30.42\left(\mathrm{COD}-\mathrm{CH}_{2}\right), 50.80\left(\mathrm{CH}_{2}-\mathrm{Fc}\right), 47.12\left(\mathrm{CH}_{2}-\right.$ Mes), 21.12 (o- $\left.\mathrm{CH}_{3} \mathrm{Mes}\right), 19.89$ (p-CH 3 Mes). ${ }^{31} \mathrm{P}\left\{{ }^{1} \mathrm{H}\right\} \mathrm{NMR}(121.5 \mathrm{MHz}$, $\left.\mathrm{CDCl}_{3}, 25^{\circ} \mathrm{C}\right): \delta=18.4\left(\mathrm{~d}, J_{\mathrm{P}, \mathrm{Rh}}=154.3 \mathrm{~Hz}\right) \mathrm{ppm}$.

Rhodium complex 7b: $t$-BuOK (19 mg, $0.171 \mathrm{mmol})$ and $[\mathrm{Rh}(\mathrm{COD}) \mathrm{Cl}]_{2}$ (38.5 mg, $0.078 \mathrm{mmol})$ were placed in a Schlenk tube, the solids were degassed and THF $(10 \mathrm{~mL})$ was added. The solution was stirred for $30 \mathrm{~min}$ at room temperature, then slowly added to $5 \mathbf{b}(117 \mathrm{mg}, 0.156 \mathrm{mmol})$, which was precooled to $-78^{\circ} \mathrm{C}$. The mixture was stirred at $-78^{\circ} \mathrm{C}$ for 15 min then $2 \mathrm{~h}$ at room temperature. The solvent was evaporated and the residue taken up into degassed $\mathrm{CH}_{2} \mathrm{Cl}_{2}(10 \mathrm{~mL})$. $\mathrm{AgBF}_{4}(45.6 \mathrm{mg}, 0.234 \mathrm{mmol})$ was added, the mixture was stirred for $30 \mathrm{~min}$ at room temperature and then filtered on Celite ${ }^{\oplus}$. The solvent was evaporated in vacuo and the residue was filtered on silica gel (eluent: $\mathrm{CH}_{2} \mathrm{Cl}_{2} /$ acetone 95:5) to give $\mathbf{7 b}$ as an orange solid (126 mg, $84 \%$ yield). $\mathrm{C}_{50} \mathrm{H}_{53} \mathrm{BF}_{4} \mathrm{FeN}_{2} \mathrm{PRh}$ (957.6): Calcd: $\mathrm{C}$ 62.66, H 5.54, N 2.92; found: C 61.40, H 5.66, N 2.89. ${ }^{1} \mathrm{H}$ NMR (300 MHz, $\left.\mathrm{CDCl}_{3}, 25^{\circ} \mathrm{C}\right): \delta=7.51-7.39(\mathrm{~m}, 10 \mathrm{H}, \mathrm{Ar}-H), 7.33(\mathrm{~s}, 1 \mathrm{H}$, benzimidazole), 5.39 (s, $1 \mathrm{H}$, benzimidazole), $6.94(\mathrm{~s}, 2 \mathrm{H}, \mathrm{Mes}), 5.33\left(\mathrm{~d}, J_{\mathrm{H}, \mathrm{H}}=9 \mathrm{~Hz}, 2 \mathrm{H}\right.$, $\mathrm{CH}_{2}$-Mes), 4.87 (d, $J_{\mathrm{H}, \mathrm{H}}=15 \mathrm{~Hz}, 2 \mathrm{H}, \mathrm{CH}_{2}$-Fc), 4.48, 4.45, 4.25, 4.15 (s, 8H, $\mathrm{Cp}$ ), 5.14 (s, 2H, COD-CH), 4.38 (s, 2H, COD-CH), 2.52 (s, 4H, COD$\mathrm{CH}_{2}$ ), 2.41 (s, 4H, COD-CH${ }_{2}$ ), 2.39 (s, 6H, $o$ - $\mathrm{CH}_{3} \mathrm{Mes}$ ), 1.99 (s, 3H, $p-\mathrm{CH}_{3}$ Mes) 1.81 (s, $6 \mathrm{H}, \mathrm{CH}_{3}$ benzimidazole). ${ }^{13} \mathrm{C}\left\{{ }^{1} \mathrm{H}\right\} \mathrm{NMR}\left(75.5 \mathrm{MHz}, \mathrm{CDCl}_{3}\right.$, $\left.25^{\circ} \mathrm{C}\right): \delta=189.84\left(\mathrm{~d}, J_{\mathrm{Rh}, \mathrm{C}}=50.7 \mathrm{~Hz}, \mathrm{C}_{\text {carbene }}\right), 139.69,138.68,134.27$, $134.10,133.87,132.80,132.67,131.64,130.86,129.33,129.19,128.75$, 128.62, 126.40, 111.87, 110.87 (Ar-C), 129.60 (Mes), 71.31, 69.91, 69.24, $68.43(\mathrm{Cp}), 98.89,96.47,96.33,73.58(\mathrm{COD}-\mathrm{CH}), 30.93,30.43,22.34$ (COD-CH$\left.)_{2}\right), 50.52\left(\mathrm{CH}_{2}-\mathrm{Fc}\right), 46.99\left(\mathrm{CH}_{2}-\mathrm{Mes}\right), 21.06\left(o-\mathrm{CH}_{3} \mathrm{Mes}\right), 20.57$, $20.26\left(p-\mathrm{CH}_{3} \mathrm{Mes}\right), 19.89\left(\mathrm{CH}_{3}\right.$ benzimidazole). ${ }^{31} \mathrm{P}\left\{{ }^{1} \mathrm{H}\right\}$ NMR (121.5 $\left.\mathrm{MHz}, \mathrm{CDCl}_{3}, 25^{\circ} \mathrm{C}\right): \delta=18.55\left(\mathrm{~d}, J_{\mathrm{P}, \mathrm{Rh}}=159.2 \mathrm{~Hz}\right)$.

Rhodium complex 8a: A mixture of 6a $(116 \mathrm{mg}, 0.2 \mathrm{mmol})$ and $[\mathrm{Rh}(\mathrm{OMe})(\mathrm{COD})]_{2}(48.4 \mathrm{mg}, 0.1 \mathrm{mmol})$ in $\mathrm{CH}_{2} \mathrm{Cl}_{2}(5 \mathrm{~mL})$ was stirred at room temperature for $6 \mathrm{~h}$. The volume of the solvent was reduced to $2 \mathrm{~mL}$, 
pentane $(10 \mathrm{~mL})$ was added and the yellow precipitate was recovered by filtration. The residue was purified by column chromatography on silica gel (eluent: $\mathrm{CH}_{2} \mathrm{Cl}_{2}$ ) to give a yellow-orange solid $(135 \mathrm{mg}, 86 \%$ yield). $\mathrm{C}_{36} \mathrm{H}_{40} \mathrm{FeIN}{ }_{2} \mathrm{Rh}$ (785.7): Calcd: C 54.98, H 5.09, N 3.56; found: C 52.85, H 4.71, N 3.32. ${ }^{1} \mathrm{H}$ NMR $\left(250 \mathrm{MHz}, \mathrm{CDCl}_{3}, 25^{\circ} \mathrm{C}\right): \delta=7.21\left(\mathrm{~d}, J_{\mathrm{H}, \mathrm{H}}=15 \mathrm{~Hz}\right.$, $1 \mathrm{H}$, benzimidazole), $6.94\left(\mathrm{t}, J_{\mathrm{H}, \mathrm{H}}=7.5 \mathrm{~Hz}, 1 \mathrm{H}\right.$, benzimidazole $), 6.78\left(\mathrm{t}, J_{\mathrm{H}, \mathrm{H}}\right.$ $=7.5 \mathrm{~Hz}, 1 \mathrm{H}$, benzimidazole), 6.32 benzimidazole), 6.95 (s, $2 \mathrm{H}, \mathrm{Mes}), 6.10$ (t, $\left.J_{\mathrm{H}, \mathrm{H}}=12.5 \mathrm{~Hz}, 2 \mathrm{H}, \mathrm{CH}_{2}-\mathrm{Mes}\right), 5.83\left(\mathrm{q}, J_{\mathrm{H}, \mathrm{H}}=15 \mathrm{~Hz}, 2 \mathrm{H}, \mathrm{CH}_{2}-\mathrm{Fc}\right), 4.83$ $\left(\mathrm{d}, J_{\mathrm{H}, \mathrm{H}}=1.8 \mathrm{~Hz}, 2 \mathrm{H}, \mathrm{Cp}\right), 4.48\left(\mathrm{~d}, J_{\mathrm{H}, \mathrm{H}}=1.8 \mathrm{~Hz}, 2 \mathrm{H}, \mathrm{Cp}\right), 4.35(\mathrm{~s}, 2 \mathrm{H}, \mathrm{Cp})$, $4.19\left(\mathrm{t}, J_{\mathrm{H}, \mathrm{H}}=1.8 \mathrm{~Hz}, 2 \mathrm{H}, \mathrm{Cp}\right), 5.52,5.39(\mathrm{~s}, 2 \mathrm{H}, \mathrm{COD}-\mathrm{CH}), 3.66(\mathrm{~s}, 2 \mathrm{H}$, COD-CH), 2.49 (s, 4H, COD-CH $H_{2}$ ), 1.94 (s, 4H, COD-CH $H_{2}$ ), 2.37 (s, 3H, p$\mathrm{CH}_{3} \mathrm{Mes}$ ), 2.32 (s, $\left.6 \mathrm{H}, o-\mathrm{CH}_{3} \mathrm{Mes}\right) .{ }^{13} \mathrm{C}\left\{{ }^{1} \mathrm{H}\right\} \mathrm{NMR}\left(62.9 \mathrm{MHz}, \mathrm{CDCl}_{3}, 25\right.$ $\left.{ }^{\circ} \mathrm{C}\right): \delta=196.38\left(\mathrm{~d}, J_{\mathrm{Rh}, \mathrm{C}}=50.6 \mathrm{~Hz}, \mathrm{C}_{\text {carbene }}\right), 138.82,138.53,135.86,134.69$, 128.20, 122.05, 121.47, 110.71, 110.60 (Ar-C), 129.51 (Mes), 82.08, 71.15, 69.50, 69.22, 68.91, 67.76 (Cp), 97.74, 97.63, 97.55, 97.44, 72.50, 72.28, 72.11, 71.89 (COD-CH), 32.73, 32.08, 30.16, $29.00\left(\right.$ COD- $\left.\mathrm{CH}_{2}\right), 50.45$ ( $\mathrm{CH}_{2}$-Mes), $49.92\left(\mathrm{CH}_{2}-\mathrm{Fc}\right), 21.11$ ( $\left.p-\mathrm{CH}_{3} \mathrm{Mes}\right) 21.07$ (o- $\left.\mathrm{CH}_{3} \mathrm{Mes}\right)$.

Rhodium complex 8b: A mixture of $6 \mathbf{b}(121 \mathrm{mg}, 0.2 \mathrm{mmol})$ and $[\mathrm{Rh}(\mathrm{OMe})(\mathrm{COD})]_{2}(48.4 \mathrm{mg}, 0.1 \mathrm{mmol})$ in $\mathrm{CH}_{2} \mathrm{Cl}_{2}(5 \mathrm{~mL})$ was stirred at room temperature for $6 \mathrm{~h}$. The volume of the solvent reduced to $2 \mathrm{~mL}$, pentane $(10 \mathrm{~mL})$ was added and the yellow precipitate was recovered by filtration. The residue was purified by column chromatography on silica gel (eluent: $\mathrm{CH}_{2} \mathrm{Cl}_{2}$ ) to give a yellow-orange solid (138 mg, $84 \%$ yield). $\mathrm{C}_{38} \mathrm{H}_{44} \mathrm{FeIN}{ }_{2} \mathrm{Rh}$ (813.7): Calcd: C 56.04, H 5.41, N 3.44; found: C 56.85, H 5.81, N 3.33. ${ }^{1} \mathrm{H}$ NMR ( $\left.300 \mathrm{MHz}, \mathrm{CDCl}_{3}, 25{ }^{\circ} \mathrm{C}\right): \delta=6.97(\mathrm{~s}, 2 \mathrm{H}$, benzimidazole), 6.95 (s, $2 \mathrm{H}, \mathrm{Mes}), 6.03\left(\mathrm{~d}, J_{\mathrm{H}, \mathrm{H}}=15 \mathrm{~Hz}, 1 \mathrm{H}, \mathrm{CH}_{2}\right.$-Mes), $6.23\left(\mathrm{~d}, J_{\mathrm{H}, \mathrm{H}}=15 \mathrm{~Hz}, 1 \mathrm{H}, \mathrm{CH}_{2}-\mathrm{Mes}\right), 5.78\left(\mathrm{q}, J_{\mathrm{H}, \mathrm{H}}=12 \mathrm{~Hz}, 2 \mathrm{H}, \mathrm{CH}_{2}-\mathrm{Fc}\right)$, $4.80\left(\mathrm{~d}, J_{\mathrm{H}, \mathrm{H}}=1.2 \mathrm{~Hz}, 2 \mathrm{H}, \mathrm{Cp}\right), 4.47\left(\mathrm{~d}, J_{\mathrm{H}, \mathrm{H}}=1.2 \mathrm{~Hz}, 2 \mathrm{H}, \mathrm{Cp}\right), 4.33\left(\mathrm{~d}, J_{\mathrm{H}, \mathrm{H}}\right.$ $=1.2 \mathrm{~Hz}, 2 \mathrm{H}, \mathrm{Cp}), 4.17\left(\mathrm{t}, J_{\mathrm{H}, \mathrm{H}}=1.2 \mathrm{~Hz}, 2 \mathrm{H}, \mathrm{Cp}\right), 5.46,5.35(\mathrm{~s}, 2 \mathrm{H}, \mathrm{COD}-$ $\mathrm{CH}$ ), 3.60 (s, 2H, COD-CH), 2.47 (s, 4H, COD-CH $\mathrm{CH}_{2}, 1.95$ (s, 4H, COD$\mathrm{CH}_{2}$ ), 2.37 (s, 3H, $p$ - $\mathrm{CH}_{3} \mathrm{Mes}$ ), 2.31 (s, 6H, $o-\mathrm{CH}_{3} \mathrm{Mes}$ ), 2.17 (s, 6H, $\mathrm{CH}_{3}$ benzimidazole). ${ }^{13} \mathrm{C}\left\{{ }^{1} \mathrm{H}\right\}$ NMR $\left(75.5 \mathrm{MHz}, \mathrm{CDCl}_{3}, 25{ }^{\circ} \mathrm{C}\right): \delta=194.51(\mathrm{~d}$, $\left.J_{\mathrm{Rh}, \mathrm{C}}=50.8 \mathrm{~Hz}, \mathrm{C}_{\text {carbene }}\right), 138.83,138.37,134.51,133.32,130.61,130.26$, 129.35, 128.56, 111.15 (Ar-C), 129.47 (Mes), 82.43, 71.07, 69.38, 68.76, 67.69 (Cp), 97.36, 97.27, 97.16, 97.08, 72.35, 72.16, 71.98, 71.80 (COD$\mathrm{CH}), 32.70,32.10,30.11,29.03\left(\mathrm{COD}-\mathrm{CH}_{2}\right), 50.08\left(\mathrm{CH}_{2}-\mathrm{Mes}\right), 49.68$ $\left(\mathrm{CH}_{2}-\mathrm{Fc}\right), \quad 21.06 \quad\left(p-\mathrm{CH}_{3} \quad \mathrm{Mes}\right) \quad 20.29 \quad\left(o-\mathrm{CH}_{3} \quad \mathrm{Mes}\right), \quad 20.15 \quad\left(\mathrm{CH}_{3}\right.$ benzimidazole).

\section{Representative procedure for $\mathbf{R h}^{\mathrm{I}}$-catalyzed hydrosilylation of ketones.}

In a flame-dried Schlenk flask was placed the $\mathrm{Rh}^{\mathrm{I}}$ complex $\left(10^{-6} \mathrm{~mol}, 2\right.$ mol\%) under argon. Anhydrous THF $(0.25 \mathrm{~mL})$ and then acetophenone (56 $\left.\mu \mathrm{L}, 4.810^{-4} \mathrm{~mol}\right)$ were added by syringe. Diphenylsilane $\left(100 \mu \mathrm{L}, 5.410^{-4}\right.$ mol) was added slowly, the reaction mixture was stirred at room temperature and the conversion of acetophenone followed by TLC analysis. After the reaction was finished, the solvent was evaporated in vacuo and the residue analyzed by ${ }^{1} \mathrm{H} \mathrm{NMR}\left(\mathrm{CDCl}_{3}\right)$. The NMR sample was taken up into $\mathrm{CH}_{2} \mathrm{Cl}_{2}, \mathrm{MeOH}(1 \mathrm{~mL})$ was added, the reaction mixture stirred for $1 \mathrm{~h}$ at room temperature. $1 \mathrm{M} \mathrm{HCl}(1 \mathrm{~mL})$ was then added, and the reaction mixture stirred for 1 additional hour at room temperature. The phases were separated, the aqueous phase extracted with $\mathrm{CH}_{2} \mathrm{Cl}_{2}$, the organic phases were dried $\left(\mathrm{MgSO}_{4}\right)$, filtered and concentrated in vacuo. The residue was analyzed by ${ }^{1} \mathrm{H}$ NMR.

\section{$\mathrm{X}$-ray diffraction studies.}

A single crystal of each compound was mounted under inert perfluoropolyether at the tip of glass fibre and cooled in the cryostream of either an Oxford-Diffraction XCALIBUR CCD diffractometer for $\mathbf{6 b}, \mathbf{7 b}$, $7 \mathbf{a}$ and $\mathbf{8 a}$, a Stoe IPDS diffractometer for $\mathbf{8 b}$ or a Bruker APEXII CCD diffractometer for $\mathbf{5 a}$. Data were collected using the monochromatic MoKa radiation $(\lambda=0.71073)$. The structures were solved by direct methods (SIR97) ${ }^{[40]}$ and refined by least-squares procedures on $F^{2}$ using SHELXL97. ${ }^{[41]}$ All $\mathrm{H}$ atoms attached to carbon were introduced in calculation in idealised positions and treated as riding models. In compound $\mathbf{6 b}$, some residual electron density were difficult to model and therefore, the
SQUEEZE function of PLATON ${ }^{[42]}$ was used to eliminate the contribution of the electron density in the solvent region from the intensity data, and the solvent-free model was employed for the final refinement. There are two cavities of about $173 \AA^{3}$ per unit cell. PLATON estimated that each cavity contains 12 electrons which may correspond to half a molecule of acetonitrile as suggested by chemical analyses. In compound $\mathbf{7 b}$ and $\mathbf{8 a}$, the SQUEEZE function has been also used. In $\mathbf{7 b}$, there are two cavities of 470 $\AA^{3}$ per unit cell. PLATON estimated that each cavity contains 190 electrons which may correspond to roughly a mixture of four $\mathrm{CH}_{2} \mathrm{Cl}_{2}$ and four $\left(\mathrm{C}_{2} \mathrm{H}_{5}\right)_{2} \mathrm{O}$ molecules within the cell as suggested by the use of these solvents during the crystallization procedure. In compound 8a, there are two cavities of $172 \AA^{3}$ per unit cell, which may roughly correspond to a mixture of two $\mathrm{CH}_{2} \mathrm{Cl}_{2}$ and two $\left(\mathrm{C}_{2} \mathrm{H}_{5}\right)_{2} \mathrm{O}$ molecules within the cell. The drawing of the molecules was realised with the help of ORTEP32. ${ }^{[43]}$ Crystal data and refinement parameters are shown in Tables 4 and 5 .

Crystallographic data (excluding structure factors) have been deposited with the Cambridge Crystallographic Data Centre as supplementary publication no. CCDC 710144 - 710147 and 711381 - 711382. Copies of the data can be obtained free of charge on application to the Director, CCDC, 12 Union Road, Cambridge CB2 1EZ, UK (fax: (+44) 1223-336033; e-mail: deposit@ccdc.cam.ac.uk).

Table 4. Crystal data and structure refinement parameters for benzimidazolium salts.

\begin{tabular}{|c|c|c|}
\hline Compound & $5 \mathbf{a}$ & 6b \\
\hline Empirical formula & $\mathrm{C}_{40} \mathrm{H}_{38} \mathrm{FeN}_{2} \mathrm{P}, \mathrm{BF}_{4}$ & $\left(\mathrm{C}_{30} \mathrm{H}_{33} \mathrm{FeN}_{2}\right)_{2}, \mathrm{I}_{2}$ \\
\hline Formula weight & 720.35 & 1208.67 \\
\hline Temperature, $\mathrm{K}$ & $180(2) \mathrm{K}$ & $180(2) \mathrm{K}$ \\
\hline Wavelength, $\AA$ & 0.71073 & $0.71073 \AA$ \\
\hline Crystal system & Monoclinic & Triclinic \\
\hline Space group & $\mathrm{P} 2{ }_{1} / \mathrm{c}$ & $\mathrm{P}-1$ \\
\hline a, $\AA$ & $16.5808(16)$ & $10.0316(8)$ \\
\hline $\mathrm{b}, \AA$ & $16.7482(15)$ & $13.7879(10)$ \\
\hline $\mathrm{c}, \AA$ & $12.9508(11)$ & $22.6738(14)$ \\
\hline$\alpha,{ }^{\circ}$ & 90.0 & $103.671(6)$ \\
\hline$\beta,{ }^{\circ}$ & $92.832(5)$ & $97.411(6)$ \\
\hline$\gamma,{ }^{\circ}$ & 90.0 & $102.822(7)$ \\
\hline Volume, $\AA^{3}$ & $3592.0(6)$ & 2916.3(4) \\
\hline $\mathrm{Z}$ & 4 & 2 \\
\hline $\begin{array}{l}\text { Density (calculated), } \\
\mathrm{Mg} / \mathrm{m}^{3}\end{array}$ & 1.332 & 1.376 \\
\hline Absorption coefficient, $\mathrm{mm}^{-1}$ & 0.516 & 1.594 \\
\hline $\mathrm{F}(000)$ & 1496 & 1224 \\
\hline Crystal size, $\mathrm{mm}^{3}$ & $0.84 \times 0.163 \times 0.068$ & $0.75 \times 0.43 \times 0.26$ \\
\hline Theta range, ${ }^{\circ}$ & 2.38 to 27.02 & 2.77 to 27.10 \\
\hline Reflections collected & 120450 & 23199 \\
\hline Independent reflections $\left(\mathrm{R}_{\text {int }}\right)$ & 7757 (0.0836) & $12820(0.0407)$ \\
\hline Completeness, $\%$ & 98.7 & $99.5 \%$ \\
\hline Absorption correction & Multi-scan & Multi-scan \\
\hline Max. and min. transmission & 1.0 and 0.404 & 1.0 and 0.635 \\
\hline Refinement method & $\mathrm{F}^{2}$ & $\mathrm{~F}^{2}$ \\
\hline $\begin{array}{l}\text { Data / restraints / } \\
\text { parameters }\end{array}$ & $7757 / 0 / 445$ & $12820 / 0 / 623$ \\
\hline Goodness-of-fit on $\mathrm{F}^{2}$ & 1.031 & 1.078 \\
\hline $\mathrm{R} 1, w \mathrm{w} 2[\mathrm{I}>2 \sigma(\mathrm{I})]$ & $0.0418,0.1013$ & $0.0608,0.1374$ \\
\hline R1, wR2 (all data) & $0.0686,0.1154$ & $0.0766,0.1434$ \\
\hline Residual density, e. $\AA^{-3}$ & $0.611 /-0.467$ & $1.536 /-1.232$ \\
\hline
\end{tabular}


Table 5. Crystal data and structure refinement parameters for rhodium complexes.

\begin{tabular}{|c|c|c|c|c|}
\hline Compound & $7 \mathbf{a}$ & $7 \mathbf{b}$ & $\mathbf{8 a}$ & $\mathbf{8 b}$ \\
\hline Empirical formula & $\mathrm{C}_{46} \mathrm{H}_{45} \mathrm{FeN}_{2} \mathrm{PRh}, \mathrm{BF}_{4}$ & $\mathrm{C}_{50} \mathrm{H}_{51} \mathrm{FeN}_{2} \mathrm{PRh}, \mathrm{BF}_{4}$ & $\mathrm{C}_{36} \mathrm{H}_{40} \mathrm{FeIN}{ }_{2} \mathrm{Rh}$ & $\mathrm{C}_{38} \mathrm{H}_{44} \mathrm{FeN}{ }_{2} \mathrm{Rh}, \mathrm{I}$ \\
\hline Formula weight & 891.57 & 956.47 & 786.36 & 814.41 \\
\hline Temperature, $\mathrm{K}$ & $180(2)$ & $180(2) \mathrm{K}$ & $180(2) \mathrm{K}$ & $296(2)$ \\
\hline Wavelength, $\AA$ & 0.71073 & 0.71073 & 0.71073 & 0.71073 \\
\hline Crystal system & Monoclinic & Monoclinic & Tetragonal & Monoclinic \\
\hline Space group & $\mathrm{P} 2{ }_{1} / \mathrm{c}$ & $\mathrm{P} 2{ }_{1} / \mathrm{n}$ & $\mathrm{I}-4$ & $\mathrm{P} 2{ }_{1} / \mathrm{n}$ \\
\hline $\mathrm{a}, \AA$ & $10.4291(4)$ & $14.6210(15)$ & $28.3187(10)$ & $12.5094(14)$ \\
\hline $\mathrm{b}, \AA$ & $27.7380(12)$ & $13.7691(11)$ & $28.3187(10)$ & $15.0659(12)$ \\
\hline c, $\AA$ & $14.1065(6)$ & $24.724(2)$ & $8.0375(6)$ & $18.3417(19)$ \\
\hline$\alpha,{ }^{\circ}$ & 90.0 & 90.0 & 90.0 & 90.0 \\
\hline$\beta,^{\circ}$ & 91.019 & $91.663(3)$ & 90.0 & $98.151(13)$ \\
\hline$\gamma,{ }^{\circ}$ & 90.0 & 90.0 & 90.0 & 90.0 \\
\hline Volume, Å3 & $4080.1(3)$ & $4975.3(8)$ & $6445.7(6)$ & $3421.9(6)$ \\
\hline $\mathrm{Z}$ & 4 & 4 & 8 & 4 \\
\hline Density (calculated), $\mathrm{Mg} / \mathrm{m}^{3}$ & 1.515 & 1.277 & 1.621 & 1.581 \\
\hline Absorption coefficient, $\mathrm{mm}^{-1}$ & 0.855 & 0.703 & 1.947 & 1.837 \\
\hline $\mathrm{F}(000)$ & 1912 & 1968 & 3152 & 1640 \\
\hline Crystal size, $\mathrm{mm}^{3}$ & $0.336 \times 0.125 \times 0.080$ & $0.293 \times 0.085 \times 0.039$ & $0.44 \times 0.08 \times 0.071$ & $0.40 \times 0.40 \times 0.16$ \\
\hline Theta range, ${ }^{\circ}$ & 2.82 to 26.37 & 1.64 to 22.12 & 2.27 to 33.22 & 1.76 to 24.20 \\
\hline Reflections collected & 30948 & 79794 & 128931 & 27214 \\
\hline Independent reflections $\left(\mathrm{R}_{\text {int }}\right)$ & $8322(0.0756)$ & $6134(0.1124)$ & $12376(0.0463)$ & $5458(0.1564)$ \\
\hline Completeness, $\%$ & 99.9 & 98.8 & 99.9 & 99.0 \\
\hline Absorption correction & Multi-scan & $\begin{array}{l}\text { Semi-empirical from } \\
\text { equivalents }\end{array}$ & $\begin{array}{l}\text { Semi-empirical from } \\
\text { equivalents }\end{array}$ & Multi-scan \\
\hline Max. and min. transmission & 1.0 and 0.970 & 1.0 and 0.784 & 1.0 and 0.881 & 0.5312 and 0.4354 \\
\hline Refinement method & $\mathrm{F}^{2}$ & $\mathrm{~F}^{2}$ & $\mathrm{~F}^{2}$ & $\mathrm{~F}^{2}$ \\
\hline Data / restraints / parameters & $8322 / 51 / 526$ & $6134 / 0 / 546$ & $12376 / 1 / 373$ & $5458 / 0 / 393$ \\
\hline Goodness-of-fit on F2 & 1.243 & 1.076 & 1.035 & 0.790 \\
\hline $\mathrm{R} 1, w \mathrm{R} 2[\mathrm{I}>2 \sigma(\mathrm{I})]$ & $0.0792,0.1418$ & $0.0406,0.0978$ & $0.0294,0.0674$ & $0.0544,0.1175$ \\
\hline R1, wR2 (all data) & $0.1146,0.1500$ & $0.0598,0.1051$ & $0.0336,0.0689$ & $0.1360,0.1409$ \\
\hline Residual density, e. $\AA$-3 & $1.068 /-1.517$ & $0.508 /-0.403$ & $0.600 /-0.359$ & $1.200 /-1.130$ \\
\hline
\end{tabular}

\section{Acknowledgment}

We thank the Centre National de la Recherche Scientifique (CNRS) and the Institut Universitaire de France (IUF) for support of this work.

[1] a) P. L. Arnold, S. T. Liddle, Chem. Commun. 2006, 3959-3971; O. Kühl, Chem. Soc. Rev. 2007, 36, 592-607; b) A. T. Normand, K. J. Cavell, Eur. J. Inorg. Chem. 2008, 2781-2800; c) J. Wolf, A Labande, J.-C. Daran, R. Poli, J. Organomet. Chem. 2006, 691, 433443; d) J. Wolf, A. Labande, M. Natella, J.-C. Daran, R. Poli, J. Mol. Catal. A: Chem. 2006, 259, 205-212.

[2] a) S. Gischig, A. Togni, Organometallics 2004, 23, 2479-2487; b) H. Seo, H.-J. Park, B. Y. Kim, J. H. Lee, S. U. Son, Y. K. Chung, Organometallics 2003, 22, 618-620; c) H. Willms, W. Frank, C. Ganter, Chem. Eur. J. 2008, 14, 2719-2729.

[3] J.-c. Shi, P. Yang, Q. Tong, L. Jia, Dalton Transactions 2008, 938945.

[4] A. Labande, J.-C. Daran, E. Manoury, R. Poli, Eur. J. Inorg. Chem. 2007, 1205-1209.

[5] J. Wolf, A. Labande, J.-C. Daran, R. Poli, Eur. J. Inorg. Chem. 2007, 5069-5079.

[6] a) I. Özdemir, Y. Gök, N. Gürbüz, E. Cetinkaya, B. Cetinkaya, Heteroat. Chem. 2004, 15, 419-423; b) I. Özdemir, Y. Gök, N. Gürbüz, E. Çetinkaya, B. Çetinkaya, Synth. Commun. 2004, 34, 4135 - 4144; c) M. Dincer, N. Özdemir, S. Gülcemal, B. Çetinkaya, O. Buyukgungor, Acta Crystallogr., Sect. C: Cryst. Struct. Commun. 2006, 62, m252-m254; d) A. G. Gökçe, S. Gülcemal, M. Aygün, B. Çetinkaya, O. Büyükgüngör, Acta Crystallogr., Sect. C: Cryst. Struct.
Commun. 2006, 62, m535-m537; e) S. Demir, I. Özdemir, B. Çetinkaya, Appl. Organomet. Chem. 2006, 20, 254-259; f) M. Yigit, B. Yigit, I. Özdemir, E. Cetinkaya, B. Çetinkaya, Appl. Organomet Chem. 2006, 20, 322-327; g) M. Dincer, N. Özdemir, S. Gülcemal, B. Çetinkaya, Acta Crystallogr., Sect. C: Cryst. Struct. Commun. 2007, 63, m228-m230; h) B. Kosar, H. Türkmen, B. Çetinkaya, O. Büyükgüngür, Acta Crystallogr., Sect. E: Struct. Rep. Online 2007, 63, m619-m620; i) H. Türkmen, S. DenizaltI, I. Özdemir, E. Çetinkaya, B. Çetinkaya, J. Organomet. Chem. 2008, 693, 425-434; j) S. Yasar, I. Özdemir, B. Çetinkaya, J.-L. Renaud, C. Bruneau, Eur J. Org. Chem. 2008, 2008, 2142-2149; k) M. S. Jeletic, I. Ghiviriga K. A. Abboud, A. S. Veige, Organometallics 2007, 26, 5267-5270.

[7] I. Özdemir, N. Sahin, Y. Gök, S. Demir, B. Çetinkaya, J. Mol. Catal. A: Chem. 2005, 234, 181-185.

[8] W.-L. Duan, M. Shi, G.-B. Rong, Chemical Communications 2003, 2916-2917

[9] a) W. A. Herrmann, J. Schutz, G. D. Frey, E. Herdtweck, Organometallics 2006, 25, 2437-2448; b) T. Chen, X.-G. Liu, M. Shi, Tetrahedron 2007, 63, 4874-4880.

[10] R. J. Lowry, M. K. Veige, O. Clément, K. A. Abboud, I. Ghiviriga, A. S. Veige, Organometallics 2008, 27, 5184-5195.

[11] O. Buisine, G. Berthon-Gelloz, J.-F. Briere, S. Sterin, G. Mignani, P Branlard, B. Tinant, J.-P. Declercq, I. E. Marko, Chem. Commun. 2005, 3856-3858.

[12] C. J. O'Brien, E. A. B. Kantchev, G. A. Chass, N. Hadei, A. C Hopkinson, M. G. Organ, D. H. Setiadi, T.-H. Tang, D.-C. Fang, Tetrahedron 2005, 61, 9723-9735.

[13] F. E. Hahn, L. Wittenbecher, R. Boese, D. Bläser, Chem. Eur. J. 1999, $5,1931-1935$ 
[14] a) C. Bolm, M. Kesselgruber, G. Raabe, Organometallics 2002, 21 , 707-710; b) Y. Yuan, G. Raabe, C. Bolm, J. Organomet. Chem. 2005, $690,5747-5752$

[15] a) B. Bildstein, M. Malaun, H. Kopacka, K.-H. Ongania, K. Wurst, Journal of Organometallic Chemistry 1998, 552, 45-61; b) B. Bildstein, M. Malaun, H. Kopacka, K.-H. Ongania, K. Wurst, J. Organomet. Chem. 1999, 572, 177-187.

[16] 2b was prepared according to a slightly modified procedure from ref. [7]: $n-\mathrm{BuOH}$ was used instead of EtOH.

[17] F. Demirhan, Ö. Yildirim, B. Çetinkaya, Transition Met. Chem. 2003, $28,558-562$.

[18] C. Köcher, W. A. Herrmann, Journal of Organometallic Chemistry 1997, 532, 261-265.

[19] A. S. Veige, M. S. Jeletic, R. J. Lowry, USA, 2008, p. 39pp.

[20] L. D. Field, B. A. Messerle, K. Q. Vuong, P. Turner, Organometallics 2005, 24, 4241-4250.

[21] a) H. Seo, B. Y. Kim, J. H. Lee, H.-J. Park, S. U. Son, Y. K. Chung, Organometallics 2003, 22, 4783-4791; b) M. Poyatos, M. Sanaú, E. Peris, Inorg. Chem. 2003, 42, 2572-2576; c) M. V. Baker, S. K. Brayshaw, B. W. Skelton, A. H. White, Inorg. Chim. Acta 2004, 357, 2841-2849; d) G. T. S. Andavan, E. B. Bauer, C. S. Letko, T. K. Hollis, F. S. Tham, J. Organomet. Chem. 2005, 690, 5938-5947; e) H. Karabiyik, R. Kilinçarslan, M. Aygün, B. Çetinkaya, O Büyükgüngür, J. Coord. Chem. 2007, 60, 393 - 399.

[22] a) A. R. Chianese, R. H. Crabtree, Organometallics 2005, 24, 4432 4436; b) C. Rivera, R. H. Crabtree, J. Mol. Catal. A: Chem. 2004 222, 59-73; c) J. W. Faller, P. P. Fontaine, Organometallics 2006, 25 5887-5893.

[23] V. César, S. Bellemin-Laponnaz, H. Wadepohl, L. H. Gade, Chem. Eur. J. 2005, 11, 2862-2873.

[24] H. Nishiyama, H. Sakaguchi, T. Nakamura, M. Horihata, M. Kondo, K. Itoh, Organometallics 1989, 8, 846-848.

[25] a) H. Nishiyama, M. Kondo, T. Nakamura, K. Itoh, Organometallics 1991, 10, 500-508; b) H. Nishiyama, S. B. Park, K. Itoh, Tetrahedron: Asymmetry 1992, 3, 1029-1034; c) H. Nishiyama, S. Yamaguchi, M. Kondo, K. Itoh, J. Org. Chem. 1992, 57, 4306-4309; d) D. Cuervo, M. P. Gamasa, J. Gimeno, J. Mol. Catal. A: Chem. 2006, 249, 60-64.

[26] a) T. Hayashi, C. Hayashi, Y. Uozumi, Tetrahedron: Asymmetry 1995, 6, 2503-2506; b) H. Brunner, R. Störiko, Eur. J. Inorg. Chem 1998, 1998, 783-788.
[27] C. Reyes, A. Prock, W. P. Giering, Organometallics 2002, 21, 546554.

[28] I. Kolb, J. Hetflejs, Coll. Czech. Chem. Commun. 1980, 45, 28082816.

[29] T. E. Waldman, G. Schaefer, D. P. Riley, ACS Symp. Ser. 1993, 517, 58-74.

[30] I. Ojima, M. Nihonyanagi, T. Kogure, M. Kumagai, S. Horiuchi, K. Nakatsugawa, J. Organomet. Chem. 1975, 94, 449-461.

[31] a) R. Corriu, J. J. E. Moreau, J. Organomet. Chem. 1975, 85, 19-33; b) I. Ojima, T. Kogure, M. Kumagai, S. Horiuchi, T. Sato, J. Organomet. Chem. 1976, 122, 83-97.

[32] T. Imamoto, T. Itoh, Y. Yamanoi, R. Narui, K. Yoshida, Tetrahedron: Asymmetry 2006, 17, 560-565.

[33] M. F. Lappert, R. K. Maskell, J. Organomet. Chem. 1984, 264, 217 228.

[34] J. E. Hill, T. A. Nile, J. Organomet. Chem. 1977, 137, 293-300.

[35] A. K. Roy, Volume 55 ed. (Ed.: A. F. H. a. M. J. F. Robert West), Academic Press, 2007, pp. 1-59.

[36] a) I. Ojima, T. Kogure, M. Kumagai, J. Org. Chem. 1977, 42, 16711679; b) R. Kuwano, M. Sawamura, J. Shirai, M. Takahashi, Y. Ito, Bull. Chem. Soc. Jpn. 2000, 73, 485-496; c) T. Imamoto, T. Itoh, Y. Yamanoi, R. Narui, K. Yoshida, Tetrahedron: Asymmetry 2006, 17 , 560-565.

[37] a) T.-Y. Dong, L.-L. Lai, J. Organomet. Chem. 1996, 509, 131-134; b) T.-Y. Dong, P.-H. Ho, C.-K. Chang, J. Chin. Chem. Soc. 2000, 47, 421-424.

[38] R. Uson, L. A. Oro, J. A. Cabeza, Inorg. Synth. 1995, 23, 126-130.

[39] D. Lednicer, C. R. Hauser, Org. Synth. 1960, 40, 31

[40] A. Altomare, M. C. Burla, M. Camalli, G. L. Cascarano, C Giacovazzo, A. Guagliardi, A. G. G. Moliterni, G. Polidori, R. Spagn, J. Appl. Cryst. 1999, 32, 115-119.

[41] G. M. Sheldrick, SHELXL97, Göttingen, Germany, 1998.

[42] A. L. Spek, J. Appl. Cryst. 2003, 36, 7-13.

[43] L. J. Farrugia, J. Appl. Cryst. 1997, 30, 565.

Received: ((will be filled in by the editorial staff)) Published online: ((will be filled in by the editorial staff)) 
Entry for the Table of Contents ((Please choose one layout.))

\section{Layout 1:}

Ferrocenyl benzimidazol-2-ylidene $\mathbf{R h}^{\mathrm{I}}$ complexes

Precursors of new ferrocenyl phosphane-benzimidazol-2-ylidene bifunctional ligands, and monodentate ferrocenyl benzimidazol-2-ylidene ligands, have been prepared. Cationic and neutral rhodium(I) complexes showed good activities for the catalytic hydrosilylation of ketones. The use of bidentate ligands proved essential to obtain good selectivities in the desired alcohol.

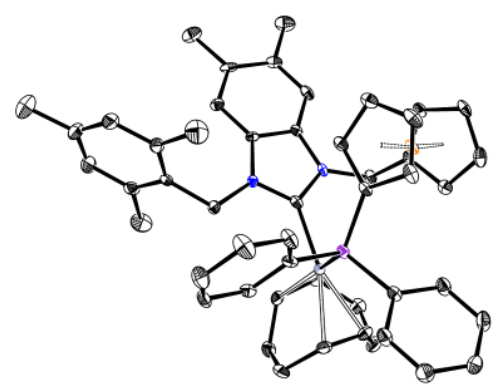

Süleyman Gülcemal, Agnès Labande,

* Jean-Claude Daran, Bekir

Çetinkaya and Rinaldo Poli

Page No. - Page No.

Rhodium(I) complexes of new ferrocenyl benzimidazol-2-ylidene ligands. The importance of chelating effect for ketone hydrosilylation catalysis.

Keywords: N-heterocyclic carbenes / benzimidazole / ferrocene / Rhodium / hydrosilylation 